LINKÖPING STUDIES IN SCIENCE AND TECHNOLOGY

THESIS NO. 1669

\title{
EXPLORING PRODUCT LIFE-CYCLE INFORMATION FLOWS WITH A FOCUS ON REMANUFACTURING
}

Division of Manufacturing Engineering Department of Management and Engineering

Linköping University 58183 Linköping

Sweden 
ISBN 978-91-7519-296-3

ISSN 0280-7971

Copyright $($ ) Louise Lindkvist

louise.lindkvist@liu.se

URL: www.iei.liu.se/indprod

Published and distributed by:

Division of Manufacturing Engineering

Department of Management and Engineering

Linköping University

58183 Linköping

Sweden

Printed by

LiU-Tryck, Linköping 2014 


\section{ABSTRACT}

Our daily lives and welfare rely heavily on products. Considering that climate change is caused by humans, it is important to handle and use products in a sustainable manner; remanufacturing is one such way to accomplish this. Remanufacturing is an industrial process where products are restored into useful life. However, few products are designed for remanufacturing, which sometimes makes remanufacturing impossible or difficult to perform. Traditionally, the design focus has been on the manufacturing and use phases. The product lifecycle perspective, however, is required to obtain a more sustainable product lifecycle.

As the remanufacturing process is characterised by process steps such as inspection, disassembly, cleaning and reprocessing, the often labour-intensive remanufacturing process has specific requirements on the design. Further, the remanufacturing process is characterised by uncertainties such as when used products are expected and what state they will be in when they arrive. Information from the product life-cycle such as drawings and service reports could potentially facilitate the remanufacturing process. Further, feedback from remanufacturing to product design could improve the design of the next generation of products.

The objective of this thesis is to identify and analyse product life-cycle information flows with a particular focus on remanufacturing.

The design research methodology framework has been used to outline, plan and support the research. Previous research in the area has been assessed through a literature study, while the case study methodology was applied for carrying out the empirical studies. The data collection methods used in the case studies were semi-structured interviews, workshops and document analysis.

The result from the literature study shows that feedback such as suggestions for improvement from remanufacturing personnel, process data, and data about wear on components could help to improve the design of the next generation of products. Further, design changes could lead to a more efficient remanufacturing process. The three industrial cases presented in this licentiate thesis fail to explore the full potential of remanufacturing feedback to product design. All in all, remanufacturing is sufficiently included in the information flows of the product life-cycle. Design for remanufacturing is not applied in any of the industrial cases studied. 



\section{ACKNOWLEDGEMENTS}

I am grateful for the support I received from several people during my research process, and for different reasons. First, I would like to take the opportunity to thank my main supervisor, Associate Professor Erik Sundin, who has supported and guided me on my way to reach this licentiate degree. Further, I thank my cosupervisor, Professor Tomohiko Sakao, for valuable input and guidance during my research process. I would also like to thank Professor Mats Björkman for thorough review of my script. Associate professor Kerstin Johansen also has my thanks, as she has been my mentor these years, supporting me and being someone I can discuss both big and small things with.

Secondly, I would like to acknowledge VINNOVA - the Swedish Governmental Agency for Innovation Systems, the financer of the research presented in this licentiate thesis. The research was part of two projects: RPT - Resource efficient Products and services and KEAP - Design for Remanufacture through Efficient Use of Product Life-cycle data. I would like to thank the participants in the two research projects for support with information and the financing needed for the research.

Thirdly, the writing of this licentiate thesis has been facilitated thanks to Kristofer Elo's licentiate template. Not to mention my colleagues and fellow PhD students, with whom I can always discuss matters and get technical support from when needed. The research process is more enjoyable in good company.

Finally, I would like to thank my friends and family who have been supporting me and thus made my work easier. I would like to especially thank my parents Gunvor and Kenneth for their efforts in supporting me with practical matters, thus making it possible for me to carry through with trips and such related to my work. Last but not least, I want to mention my joys in life Noah and Selma for their patience and unconditional love. 



\section{APPENDED PAPERS}

The following papers were published during the research and form the foundation for this licentiate thesis:

PAPER I Lindkvist, L., and Sundin, E. (2012), Life-Cycle Information Feedback to Product Design. Proceedings of the $5^{\text {th }}$ Swedish Production Symposium 2012 pp. 99-105, Linköping Sweden November 6-8

PAPER II Lindkvist, L., and Sundin, E. (2013), The Use of Product Life-Cycle Information in a Value Chain including Remanufacturing. Proceedings of the $20^{\text {th }}$ CIRP Conference on Life Cycle Engineering 2013, pp.621-626, Singapore April 17-19

PAPER III Lindkvist, L., Sundin, E., and Sakao T. (2013), Exploring the Use of Product Life-Cycle Information in Two Value Chains Including Remanufacturing. Proceedings of the $8^{\text {th }}$ International Symposium on Environmentally Consious Design and Inverse Engineering, Eco Design conference. Jeju Island, South Korea December 4-6

Contribution in the papers:

PAPER I Louise Lindkvist performed the literature study and wrote most of the paper. Erik Sundin supported and guided the writing process. He also wrote one paragraph of the paper.

PAPER II Louise Lindkvist carried out the empirical studies and wrote the paper. Erik Sundin guided and gave input to the process.

PAPER III Louise Lindkvist carried out the empirical studies and wrote the paper. Erik Sundin and Tomohiko Sakao gave constructive feedback and helped improve the paper.

\section{OTHER PUBLICATIONS}

The following paper was submitted during the writing of this licentiate thesis.

PAPER IV Lindkvist, L., Sundin, E., and Sakao T. (2014), Exploring information exchange in the product life-cycle with respect to remanufacturing. International Journal of Automation Technology. 



\section{TABLE OF CONTENTS}

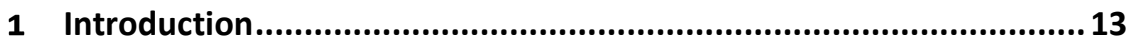

1.1 Remanufacturing and environmental aspects ..............................................13

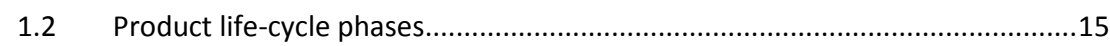

1.3 Design for remanufacturing ....................................................................15

1.4 Information feedback in the product life-cycle .........................................16

1.5 Objective and assumption..................................................................... 16

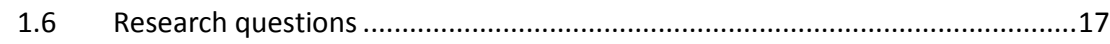

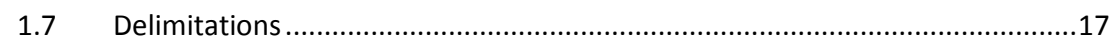

2 Research methodology ..................................................... 19

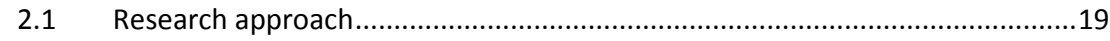

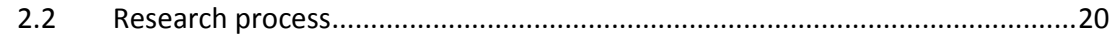

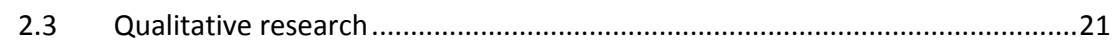

2.4 Design research methodology ..................................................................22

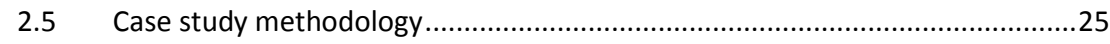

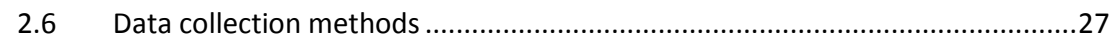

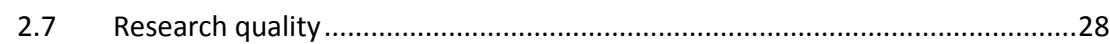

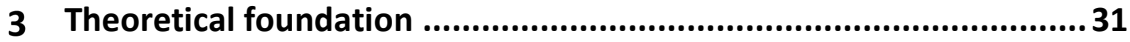

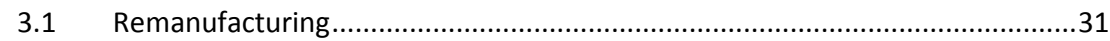

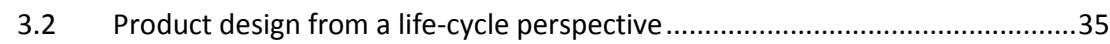

3.3 Product life-cycle information feedback to product design .............................37

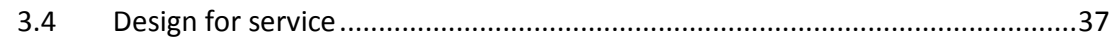

4 Results ............................................................................. 39

4.1 Product life-cycle feedback to product design...............................................39

4.2 Remanufacturing characteristics of the cases studied .................................42

4.3 Product life-cycle information flows related to remanufacturing ....................45

4.4 Product life-cycle feedback to product design in the industrial cases..............48

5 Discussion and conclusions ............................................................51

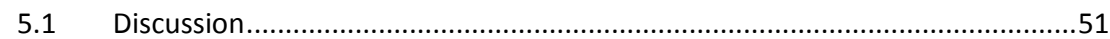

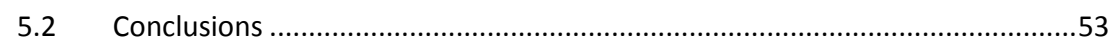

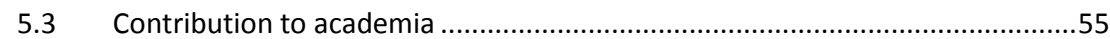

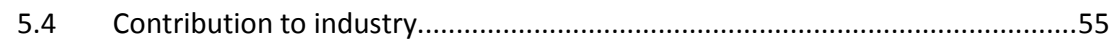

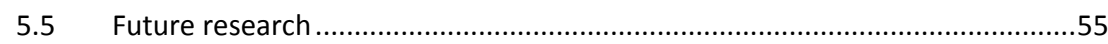

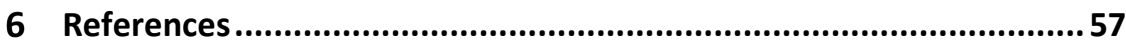

7 Appended papers

8 Appendix 


\section{LIST OF FIGURES}

Figure 1. The end-of-life hierarchy (Lee et al. 2011)........................................... 14 Figure 2. A simplified illustration of the product life-cycle with the material flows and potential information flows between the phases............................................. 15 Figure 3. The research approach in this licentiate thesis....................................... 20 Figure 4. The research process for the research presented in this licentiate thesis, presented in the sequence as it was carried out. .................................................... 21

Figure 5. Qualitative research design according to Williamson. (2002)............... 22 Figure 6. The outline of the Design Research Methodology framework by Blessing and Chakrabarti. (2009). ........................................................................ 23 Figure 7. A simplified initial reference model for the research presented in this

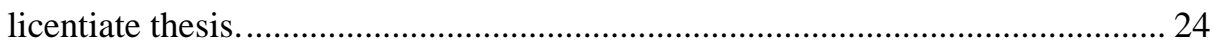
Figure 8. Holistic and embedded case studies (Yin 2004). .................................. 26 Figure 9. The four most common types of case studies according to Yin (2004).26 Figure 10. Some charachteristics of the often labour-intensive remanufacturing

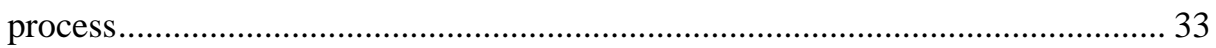
Figure 11. Examples of design for remanufacturing improvements that could be

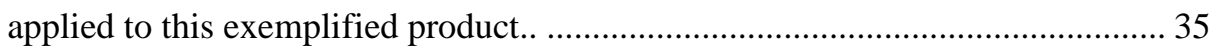
Figure 12. A product life-cycle perspective of managers as well as product

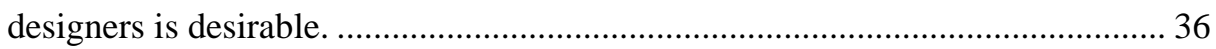
Figure 13. The remanufacturing process in Case A is linked to the rental schemes. Remanufacturing thus extend the use period for those machines......................... 43 Figure 14 The remanufacturing scheme in Case B. Remanufacturing plays only a minor part in the value chain. Material recycling is the most commonly applied

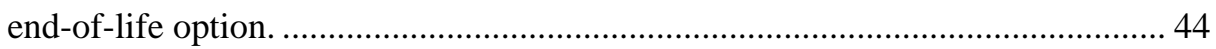
Figure 15. A schematic picture of the remanufacturing system in case $\mathrm{C}(\mathrm{OEM}=$ Original Equipment Manufacturer, $\mathrm{CR}=$ Contracted Remanufacturer). ............. 44

Figure 16. Information flows in Case A as presented in Paper III........................ 46

Figure 17. Information flows in Case B as presented in Paper III. ...................... 47

Figure 18. Information flows in Case C presented in Paper II............................. 48 


\section{LIST OF TABLES}

Table 1. Relations between research questions, methods and appended papers. . 28

Table 2. Information feedback sources and characteristics, from Paper I............. 41

Table 3. Sources of objective and subjective information feedback from the

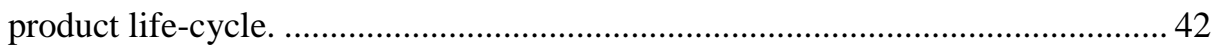

Table 4. Characteristics of the case companies presented in Paper II and III. ..... 42 Table 5. Information feedback frequency in the case companies A-C as presented

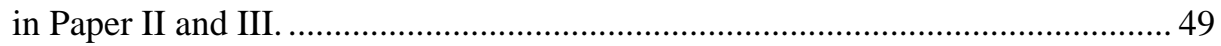





\section{INTRODUCTION}

This chapter includes a general introduction to the research area. The chapter also includes the research questions, assumption, and delimitations that were the basis for the research presented in this licentiate thesis.

\subsection{REMANUFACTURING AND ENVIRONMENTAL ASPECTS}

There is a pressing need for directed efforts addressing the sustainability issue globally. In a recent draft report (IPCC 2013), the Intergovernmental Panel on Climate Change (IPCC) concluded with 95 percent certainty that climate change is caused by humans:.

The atmospheric concentrations of carbon dioxide $\left(\mathrm{CO}_{2}\right)$, methane, and nitrous oxide have increased to levels unprecedented in at least the last 800,000 years. $\mathrm{CO}_{2}$ concentrations have increased by $40 \%$ since pre-industrial times, primarily from fossil fuel emissions and secondarily from net land use change emissions. The ocean has absorbed about 30\% of the emitted anthropogenic carbon dioxide, causing ocean acidification. (IPCC 2013)

Nature is suffering the consequences of our modern societies and there is a need to take measures and step up efforts to tackle sustainability in many areas. Our daily lives and welfare rely heavily on products and services; it is important, therefore, that the manufacturing and use of those products and services are environmentally sustainable. There is also a need to return products to a useful life in a sustainable manner, in order to minimize waste. In accordance with the end-of-life hierarchy (Figure 1), reusing products 


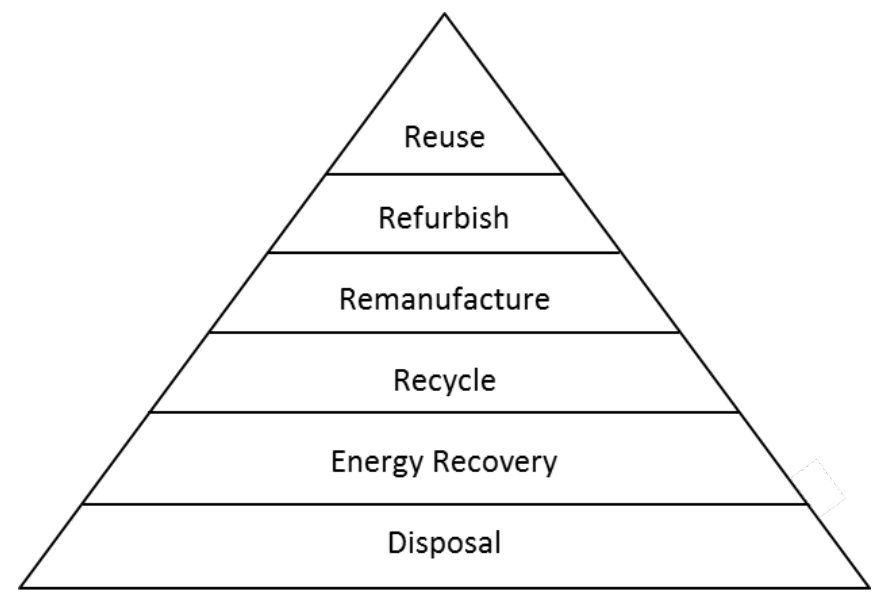

Figure 1. The end-of-life hierarchy (Lee et al. 2011).

and remanufacturing them are preferable options to recycling, where the products are separated and materials separated and reused in different applications.

Remanufacturing is the industrial process of restoring used products into "good as new" condition (Ijomah et al. 2007). Thus, remanufacturing enables reuse without first recycling the entire product. Therefore, remanufacturing is more environmentally friendly from a material resource perspective than new manufacturing (Lindahl 2006). However, the benefits from remanufacturing are highly context-related. For remanufactured products that require more energy during the use phase than new products, remanufacturing may not be the best option for the environment. However, for products that require no energy during the use phase or the same energy as new ones, remanufacturing can save energy (Gutowski et al. 2011).

Since many studies show that remanufacturing is indeed good for the environment (Sundin and Lee 2011), increasing the number of products that are remanufactured is one relevant approach to tackle the environmental issues and reduce the environmental impact caused by humans. It is therefore important that the mind-set when designing products changes, from being focused on manufacturing and use to also including activities later in the product life-cycle, such as service and remanufacturing. In fact, product designers should determine the end-of-life strategy in the design phase (Fukushige et al. 2011). 


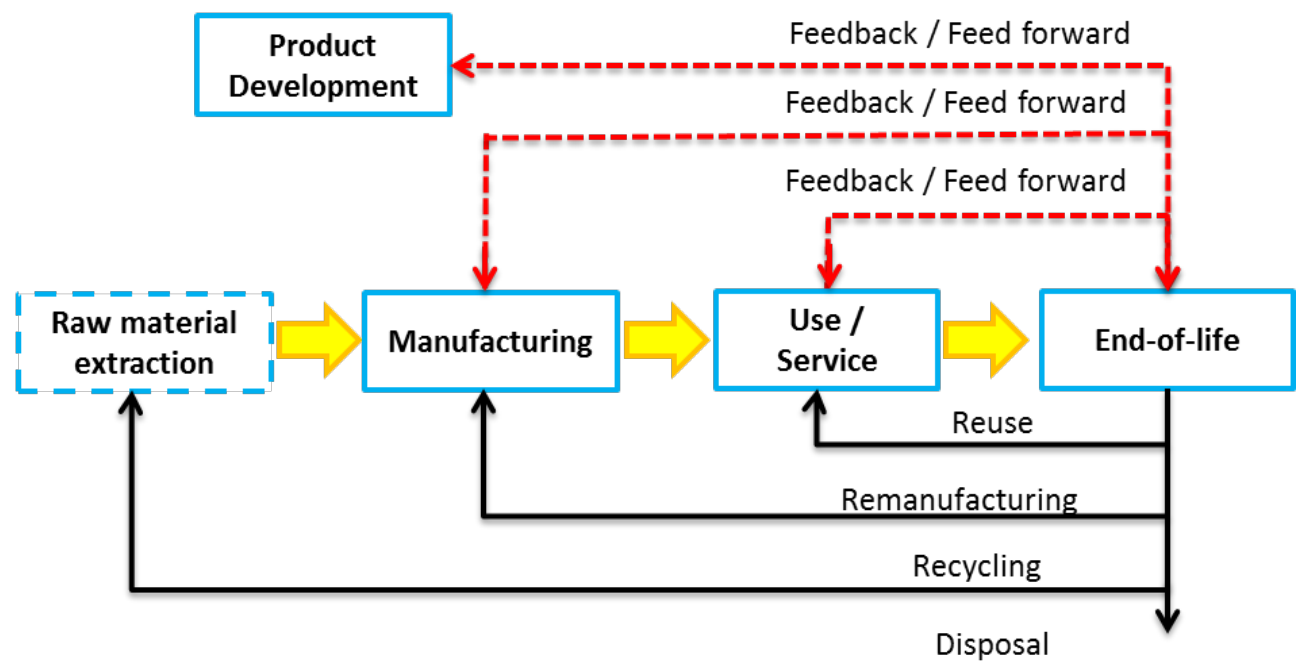

$=$ Linear material flows $\longrightarrow=$ Reverse material flows $---\Rightarrow=$ Information flows

Figure 2. A simplified illustration of the product life-cycle with the material flows and potential information flows between the phases.

\subsection{PRODUCT LIFE-CYCLE PHASES}

The predefined phases in the product life-cycle are design, manufacturing, service and remanufacturing. Their role in the product life-cycle is illustrated in Figure 2 above.

Admittedly, communication between design and manufacturing is a common subject for research and has been criticised on a general level. However, without manufacturing, there will be no products, whereas the remanufacturing part of the business has a less apparent connection to the design phase with that traditional view. The perspective needs to be lifted, from manufacturing and sales only to also include service and end-of-life (Japtag and Johnson 2011).

\subsection{DESIGN FOR REMANUFACTURING}

The remanufacturing process is characterised by certain process steps where the products are inspected, disassembled, cleaned, reprocessed etc. before they are reassembled and tested (Sundin 2004). Remanufacturing is often more labour intensive, and distinguished by uncertainties such as the timing and quality of incoming products intended for remanufacturing (Lundmark et al. 2009). The problem with many products of today is that they are not designed for remanufacturing, even though they might in fact be remanufactured (Sundin and Bras 2005, Hatcher et al. 2011a). It is important that the 
properties of the products are such that remanufacturing is facilitated. Design aspects, such as ease of disassembly and ease of cleaning, are crucial in order to meet with the requirements of an efficient and effective remanufacturing process (Sundin and Bras 2005). It is therefore desirable that remanufacturing aspects are included when planning the design of new products. Adjusting products' properties in order to facilitate remanufacturing is done through design for remanufacturing (DfRem). Thus, new products' remanufacturability can be improved through implementing remanufacturing requirements in the product design phase (Xiaoyan 2012).

\subsection{INFORMATION FEEDBACK IN THE PRODUCT LIFE-CYCLE}

In order for designers to know that their design lived up to the expectations/requirements, information feedback is commonly used, foremost from customers/users. However, widening the perspective and regarding the entire product life-cycle, there are many people interacting with a product during its lifetime(s), such as service technicians and remanufacturing staff. These people all have their specific functions and processes and thus requirements on the product design. With that perspective in mind, regarding information feedback from the entire product life-cycle in the design phase seems to be the natural next step in improving the development of sustainable products (and services). Furthermore, design provides critical information to other actors in the product life-cycle, to include customers, manufacturing, and service.

Reasoning along the same lines as above, it is likely that remanufacturing could be in need of information from design in order to have an efficient and effective process. However, one thing is to verify the information available and required in the product lifecycle; another is how that information is actually used. Although research has been carried out regarding the lack of design for remanufacturing (e.g. Hatcher et al. 2011a), research exploring the use of product life-cycle information is scarce.

\subsection{OBJECTIVE AND ASSUMPTION}

The objective of this thesis is to identify and analyse product life-cycle information flows with focus particularly on remanufacturing.

The basis for the research presented in this licentiate thesis is the following assumption:

Efficient use of product life-cycle information feedback from remanufacturing to design will lead to products better adapted for remanufacturing.

This general assumption has acted as a driver for the research carried out and presented in this licentiate thesis. The assumption is valid given that remanufacturing is included in the value chain that also designs the products. In this licentiate thesis, product life-cycle 
information was explored, and the information flows between predefined phases in the product life-cycle and remanufacturing were analysed.

\subsection{RESEARCH QUESTIONS}

In order to be able to meet the objective, the following two research questions were posed:

RQ 1 What type of information is there to be fed back to product development from the product life-cycle phases of manufacturing, use/service, and remanufacturing?

RQ 2 How is information transferred to and from remanufacturing and the product life-cycle phases of design, manufacturing, and service?

\subsection{DeLimitations}

The focus of the empirical studies is on the product life-cycle phases of product design, manufacturing, service and remanufacturing. Other actors brought up in the information flows are included based on their relation to the other previously mentioned phases. Consequently, some actors in the value chains are left out as not all actors are brought up in the responses in the interviews, and therefore the mapping of the information flows appears to be different for the different industrial cases.

The products focused on in this thesis are different in terms of complexity. This distribution of products stems from the selection criteria of the case companies. The selected case companies all include remanufacturing, functional sales and product-service systems (PSS), but to varying extents. The research only includes large companies operating on a global scale; the empirical studies, however, were carried out in Sweden.

In this licentiate thesis, only the remanufacturing original equipment manufacturers (OEMs) and contracted remanufacturers are considered. Further, in this licentiate thesis the information flows are the key factor explored, and since there is assumed to be no apparent gain for the OEM to share its information with a competitor, independent remanufacturers are excluded. Further, design changes carried out by the OEM that will ultimately gain remanufacturing are considered, thus excluding the independent remanufacturers. Indeed, OEMs have been known to adjust their product design in order to make remanufacturing more difficult and thus hinder unwanted independent remanufacturers (Sundin and Östlin 2005). 


\section{ReSEARCH METHODOLOGY}

The methods and tools used during the research are presented in this chapter. The research approach is clarified, and the methods and tools used are explained.

This chapter includes short explanations of the research approach, methods and tools used during the research presented in this licentiate thesis, namely:

- Qualitative research

- Design research methodology
- Literature study

- Case study methodology

\subsection{RESEARCH APPROACH}

The research presented in this thesis is approached both from the theoretical and empirical perspectives. From a theoretical standpoint, the purpose is to describe the overall possible information flows within the product life-cycle relating to information feedback to the product designer. An empirical approach was used in order to explore the actual information flows regarding the product design in three different case companies. The results are analysed with regard to remanufacturing and design for remanufacturing aspects. Figure 3 illustrates the research approach used for this licentiate thesis with the different methods and their internal relationships. 


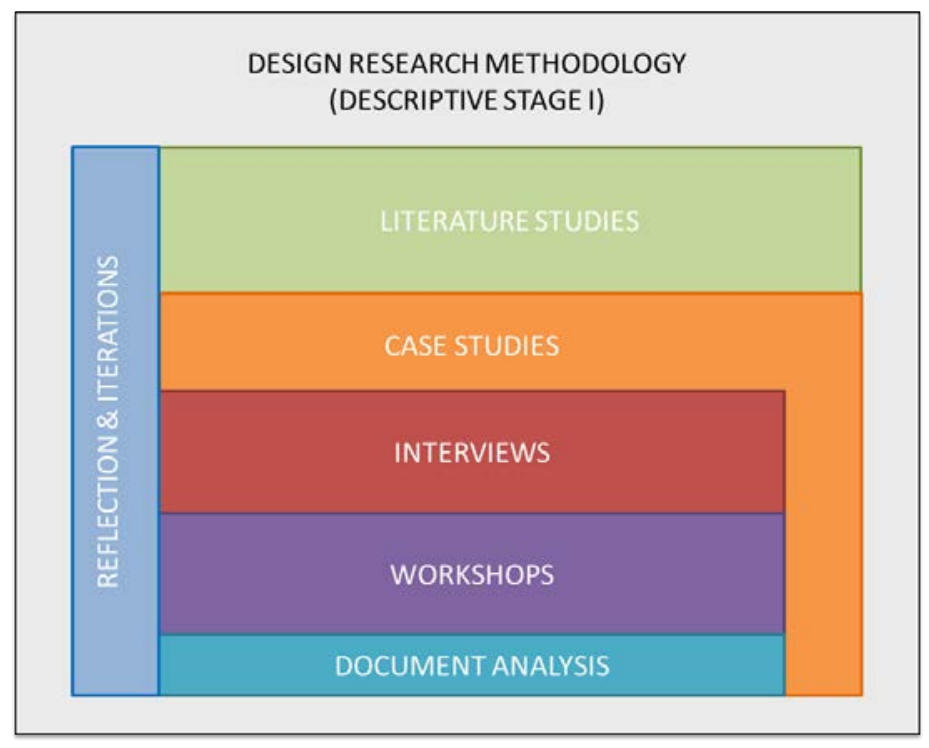

Figure 3. The research approach in this licentiate thesis.

The Design Research Methodology (DRM) framework, the case study methodology and the data collection methods are explained in the sections below. In short, the DRM framework has been used to outline, plan and support the research. The method for assessing previous research in the area has been literature study while the method for carrying out empirical studies was the case study methodology. The data collection methods used were semi-structured interviews, workshops and document analysis. An explanation of the methods is found in the coming sections. In order to be able to evaluate the work presented in this thesis, transparency concerning the research process is relevant.

\subsection{RESEARCH PROCESS}

The research process for this licentiate thesis, as illustrated in Figure 4, began with a broad literature study to identify a research gap of interest. Next, the process of planning the research and formulating research questions began. The process of analysing literature continued and a literature study paper (Paper I) was written. A pilot study was then planned and executed. This is hereafter referred to as Case C (based on how it was included as the third case at the end of Paper III). The case study led to another literature study and a paper (Paper II). Following the pilot study, two case studies (Cases A and B) were carried out and the third paper was written (Paper III). Finally, the process of writing this thesis began. Reflection, iteration and analysis have been constant features in all of these process steps. 


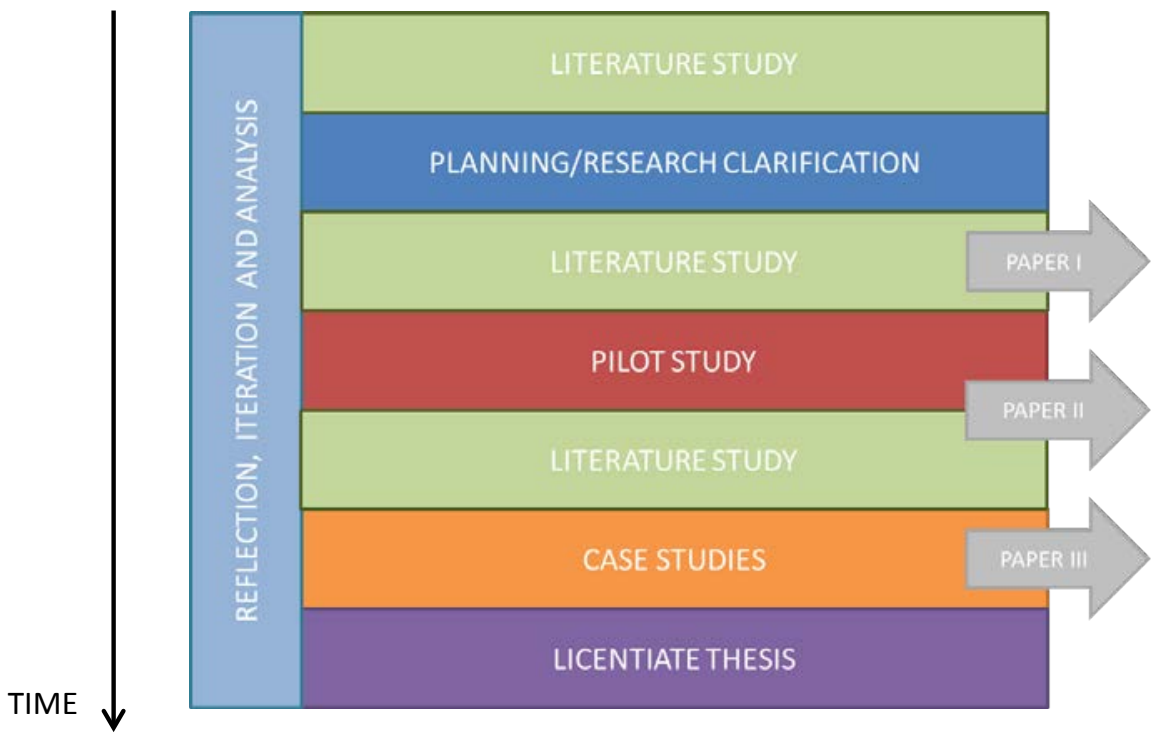

Figure 4. The research process for the research presented in this licentiate thesis, presented in the sequence as it was carried out.

\subsection{QUALITATIVE RESEARCH}

The research process presented in this licentiate thesis is qualitative in its character, and follows the general structure as outlined by Williamson (2002) in Figure 5. Based on Leedy and Ormrod (2010), a qualitative approach is preferable when e.g. the literature available is limited and the research questions are explanatory and interpretive in nature.

As the research process is also iterative in character, the plan was adjusted as the research developed. The initial literature study that proceeded the research planning gave an understanding of the challenges regarding remanufacturing and design for remanufacturing. Based on that insight, an initial research plan was outlined. 


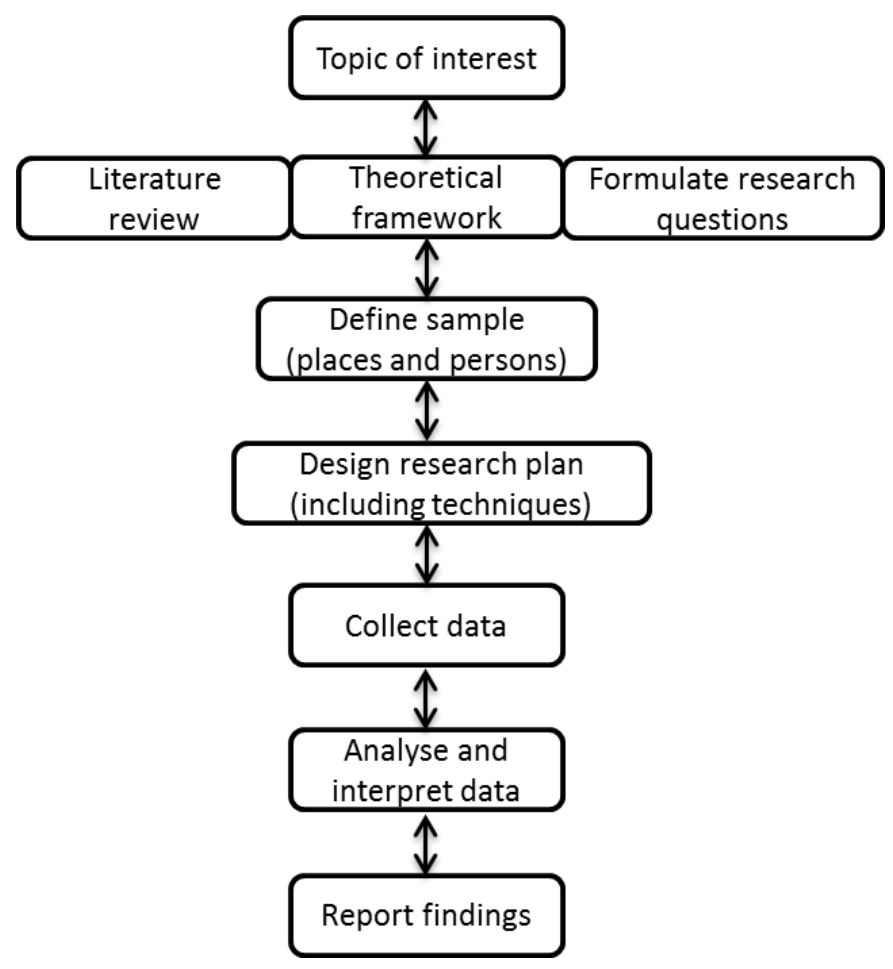

Figure 5. Qualitative research design according to Williamson. (2002).

\subsection{DESIGN RESEARCH METHODOLOGY}

The research has been carried out within the framework of the design research methodology (DRM) (Figure 6). According to Blessing \& Chakrabarti (2009), design research aims at both understanding and improving design. Thus, the DRM was chosen based on the long-term aim of the research presented in this thesis: to improve the design of products to be better adapted for remanufacturing.

Any research project should start with a research clarification (Blessing \& Chakrabarti 2009). This is carried out by reviewing the literature as well as determining the aim, focus and scope of the research project. 
Basic means

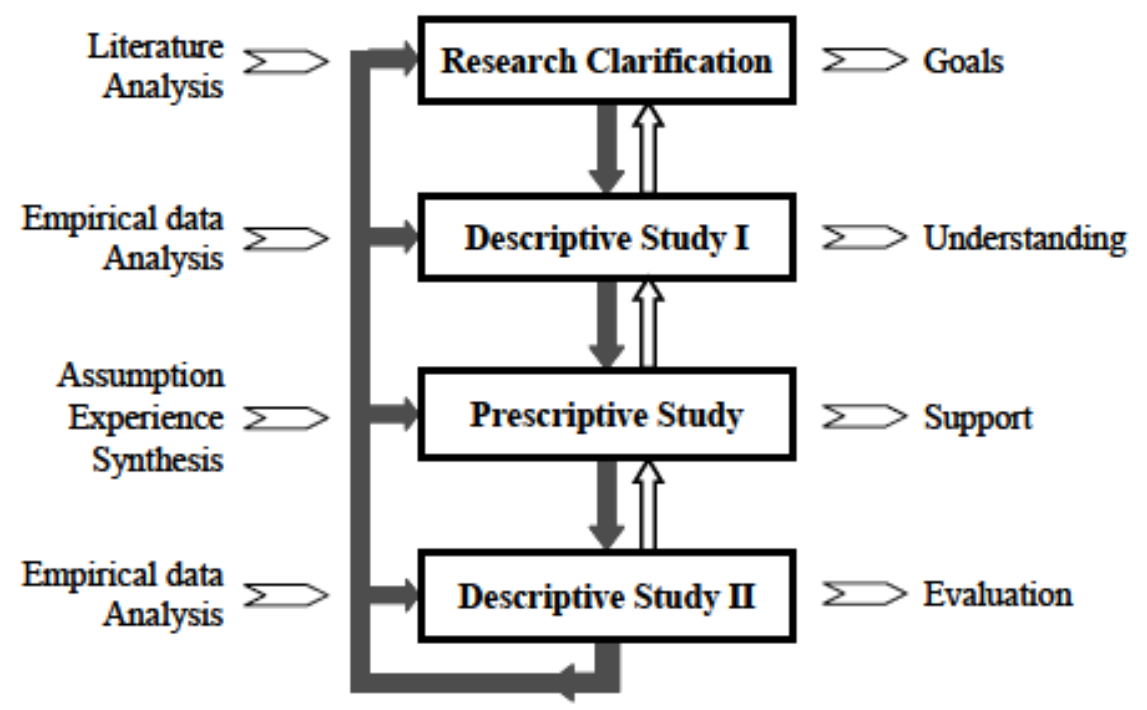

Figure 6. The outline of the Design Research Methodology framework by Blessing and Chakrabarti. (2009).

The next step is a descriptive study where the current state is explored. A descriptive study includes literature study and empirical research (Blessing \& Chakrabarti 2009). Blessing \& Chakrabarti (2009) clearly states that a descriptive case study should be followed by a prescriptive study in order to examine the application of the research findings and how they can improve the design process.

In this licentiate thesis the research clarification and descriptive study I is included. The plan is to continue with prescriptive studies after completion of the licentiate thesis.

\subsubsection{Research Clarification Stage}

According to Blessing \& Chakrabarti (2009), the aim of the research clarification stage is to identify a problem that is worthwhile focusing on, both from an academic and practical standpoint. During the research clarification stage, the research presented in this licentiate thesis was planned. Research questions were formulated and a guiding assumption was formed.

\subsubsection{INITIAL REFERENCE MODEL}

As part of the research clarification stage, an initial reference model (IRM) was created. The purpose of the model is to get a picture of the current and desired situations 
(Blessing and Chakrabarti 2009). Further, the IRM maps the research area in context to other related factors, both explicit and implicit, showing awareness of other factors that might have influence. Within the model (Figure 7), the most important instances are marked in red. The preliminary success criteria should be possible to observe on a longterm basis. This is the overall aim of the research. However, in order to be able to evaluate the research carried out during the course of a $\mathrm{PhD}$ project, a preliminary measurable success criterion is identified. This criterion needs to be measurable, and is typically assessed through an experiment or quasi-experiment (Blessing and Chakrabarti 2009). The preliminary key factor is the focus of the research. Altogether, the IRM illustrates the initial reasoning linking the studied phenomena with the desired outcome of the research preformed.

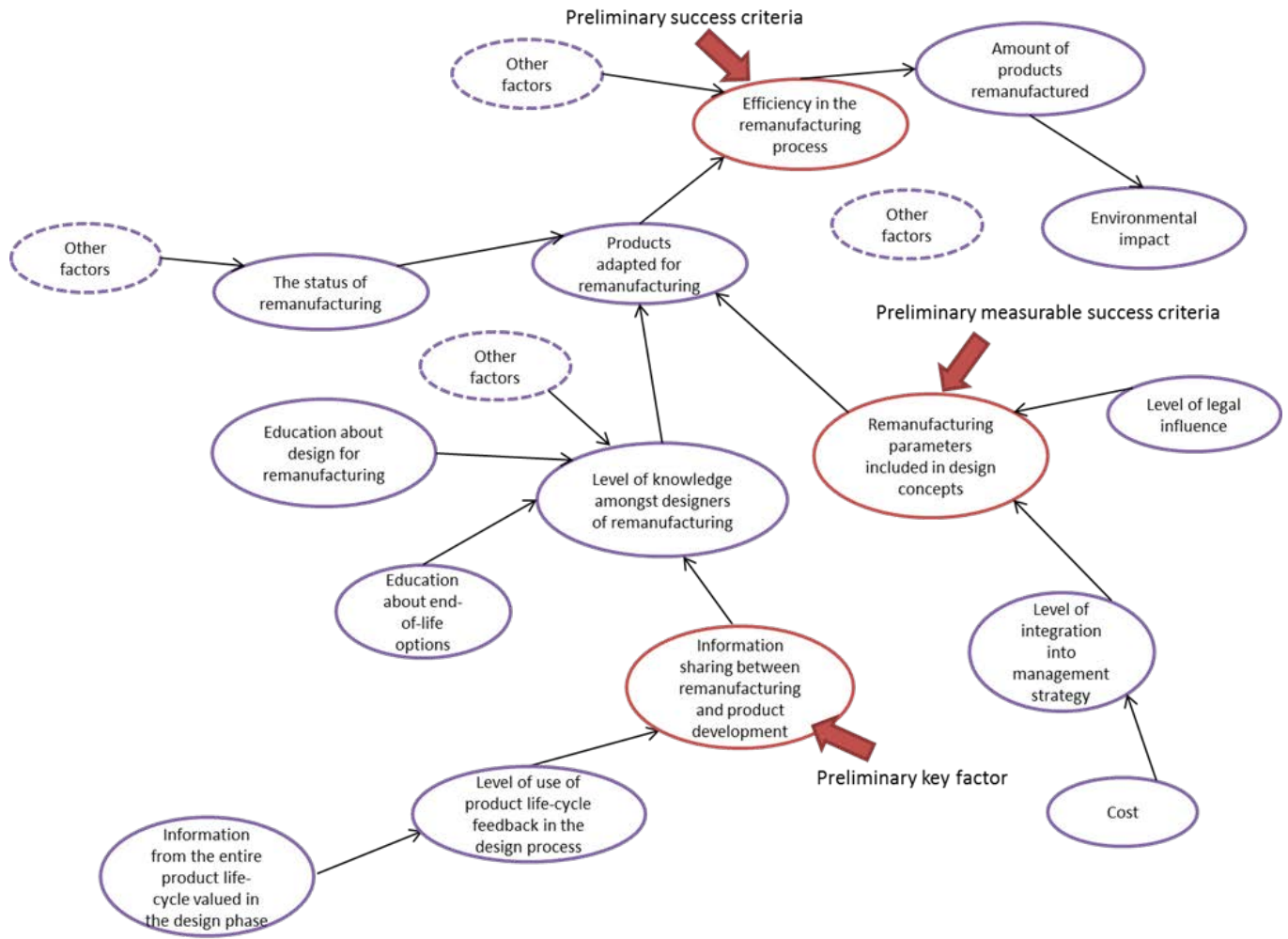

Figure 7. A simplified initial reference model for the research presented in this licentiate thesis. 


\subsubsection{DESCRIPTIVE STUDY I}

A descriptive study was then carried out in order to create an understanding of the current situation regarding product life-cycle information flows in value chains including remanufacturing.

Descriptive studies are designed to investigate current situations, both through review of the state-of-the art in the literature and by empirical studies. The outcome of a descriptive study is the understanding of the phenomena studied. The result could be in the form of theories and/or models of the aspects of product development investigated in the studies. The descriptive studies can vary in length and extent (Blessing and Chakrabarti 2009).

\subsubsection{LITERATURE STUDY}

Literature studies are done e.g. in order to find existing knowledge on a topic and to form a basis for studying a topic (Hart 1998). As such, literature studies summarises past efforts in the research field (Evans and Kowanko 2000). The literature was reviewed throughout the research process with varying intensity. A literature study was performed initially in order to understand the characteristics and challenges of remanufacturing. Based on that, an assumption and study propositions were formulated. In Paper I, a literature study is presented where the potential sources of feedback from the product life-cycle to product design are presented. Later, the literature studies were directed at better understanding different information flows within the product life-cycle.

Papers were searched for in the Science Direct and Scopus databases. Search words such as design for remanufacturing, design for service, product life-cycle information and information management were used. The emphasis was on papers focused on remanufacturing.

\subsection{CASE STUDY METHODOLOGY}

In the research presented here, the case study methodology was used to collect empirical data. Case studies are commonly used to research "how" and "why" questions (Yin 2004). Research question number two in this licentiate thesis is a "how"question, and it is answered using the case study methodology.

Case studies benefit from prior theory in order to guide data collection and analysis. Case studies also investigate a contemporary phenomenon in its true context, where the researcher requires no control over the behavioural events. Case studies are appropriate in studies where the line between phenomena and context is not clear, and for situations with many influencing variables (Yin 2004). 


\subsubsection{SINGLE-CASE STUDIES}

When single-case studies are carried out, different strategies can be applied; either one critical case is studied that tests a well-designed theory, or a case that represents an extreme or unique case is studied. Therefore, case studies demand carefully chosen cases so that they are representative of the chosen category of cases. Holistic design considers one unit of analysis, while embedded design can hold multiple units of analysis (Figure 8) (Yin 2004).
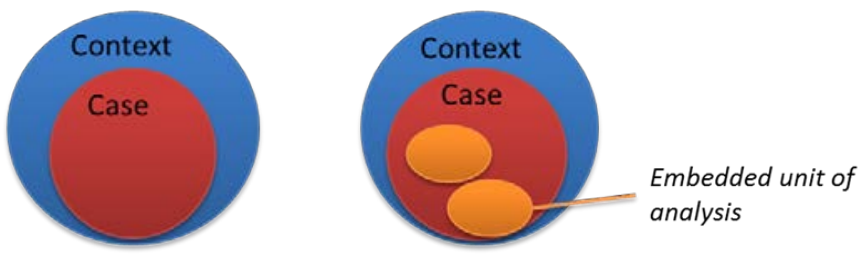

Figure 8. Holistic and embedded case studies (Yin 2004).

\subsubsection{MULTIPLE-CASE STUDIES}

Multiple-case studies are generally regarded as more robust than single-case studies. The case that is studied should be chosen with care, and it should be possible to make either a literal replication or a theoretical replication. In other words, similar results should be predictable or contrasting results should be expected for predictable reasons. Each case in itself in a multiple-case study can be either holistic or embedded (Figure 9) (Yin 2004).

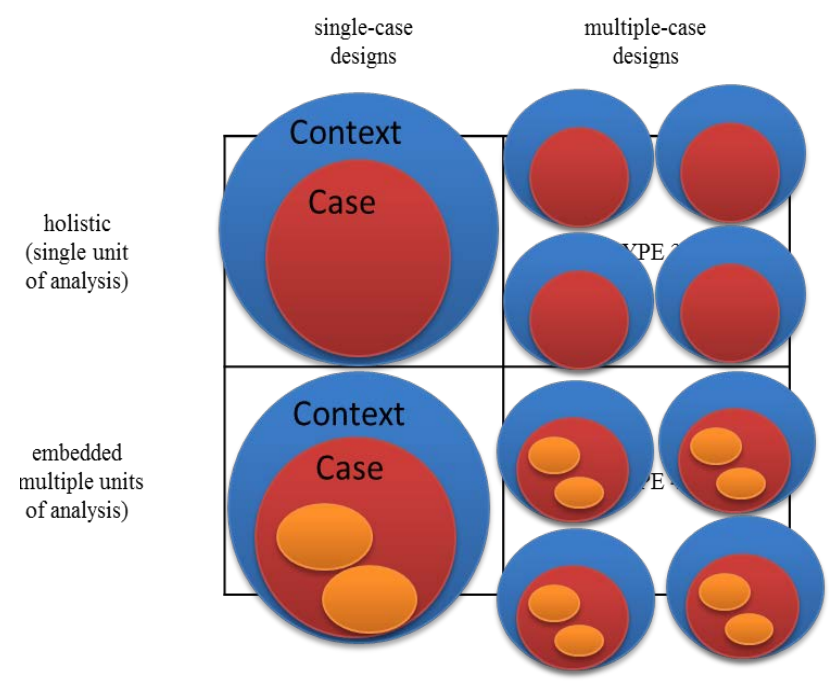

Figure 9. The four most common types of case studies according to Yin (2004). 
The research presented in this licentiate thesis has been drawn from multiple-case studies where the results have been similar as predicted. The context has been value chains that remanufacture, the cases have been large OEMs and the unit of analysis has been the information flows in the product life-cycle.

\subsubsection{PILOT STUDY}

A pilot study is designed and carried out in order to determine the feasibility of the planned research (Leedy and Ormrod 2010). The design of the case studies is based on literature studies. In this licentiate thesis, the pilot study is presented in Paper II. The research design was then evaluated, and the major outline of the initial pilot study remained for the coming case studies.

\subsection{DATA COLLECTION METHODS}

The data collection methods used are presented below

\subsubsection{SEMI-STRUCTURED INTERVIEWS}

The data collection method mainly used was semi-structured interviews. Semi-structured interviews include a list of prepared questions, but allow for the interviewer to ask follow-up questions (Williamson 2002). During the interviews the respondents were asked about the information flows in the value chains. The respondents individually brought up departments other than the key departments selected by the researcher. Those are relevant to the overall understanding of the information flows, but the analysis focuses on the preselected departments. The respondent received information beforehand about the background and scope of the interview (see Appendix). Questions considering the information flows for the selected departments were prepared beforehand. During the interview, the interviewer posed follow-up questions related to the respondent's answers for clarification. At the end of the interview, the interviewer summed up the interview and allowed the respondent to verify, elaborate on, or correct the answers. The interviews were recorded, transcribed and analysed.

\subsubsection{FOCUS GROUPS}

Focus groups were used to verify and expand on the results based on the interviews. The results from the interviews were presented in front of focus groups at Cases A and C. There, key personnel were gathered and could verify or reject the answers and discuss the conclusions and outcomes. This was also an opportunity for representatives from the selected departments to meet and broaden their knowledge of the other departments' activities and needs.

\subsubsection{DOCUMENT ANALYSIS}

Documents created by organisations can provide the researcher with insight into that organisation (Williamson 2002). Documents provided by the OEMs were used to deepen 
the understanding of the organization's internal structures. Documents depicting organisational structures, product structures etc. were accessed.

\subsubsection{Relations Between Research Questions and Methods}

The relations between the research questions, the methods used and the three appended papers are visualised in Table 1 below.

Table 1. Relations between research questions, methods and appended papers.

\begin{tabular}{|lllc|}
\hline Research question & Research method & Paper \\
\hline $\begin{array}{l}\text { RQ 1: What type of information is there to be fed back } \\
\text { to product development from the product life-cycle } \\
\text { phases of manufacturing, use/service, and } \\
\text { remanufacturing? }\end{array}$ & & I \\
\hline $\begin{array}{l}\text { RQ 2: How is information transferred to and from } \\
\text { remanufacturing and the product life-cycle phases of } \\
\text { design, manufacturing, and service? }\end{array}$ & Pilot case study & II \\
\cline { 2 - 4 } & & & Multiple-case studies \\
\hline
\end{tabular}

Literature study was chosen to analyse previous research in the field. Thus, it was possible to identify sources of information feedback available in the product life-cycle, as well as the type of information that could be retrieved from those sources. The case study methodology was applied to answer RQ 2, a "how" question, intended to study the current situation concerning information transferred to and from remanufacturing in its real context. The theoretical answers were then compared with the empirical findings of studying and analysing information flows in the product life-cycle with a focus on remanufacturing.

\subsection{RESEARCH QUALITY}

The quality of the research is analysed and presented below.

\subsubsection{VALIDATION}

According to Yin (2004), the validity of the research can be divided into internal, external and construct validity. One way to apply construct validity is to use triangulation. Patton (2002) discusses four types of triangulation: of data sources (data triangulation), among different evaluators (investigator triangulation), of perspectives on the same data set (theory triangulation), and of methods (methodological triangulation).

With triangulation, the potential problems of construct validity can be addressed. Using multiple sources of evidence addresses construct validity, since multiple measures of the 
same phenomenon are provided. In the studies conducted for this research, data and theory triangulation were applied.

In this research, validation was created through data triangulation. The respondents were interviewed, and then the interviewer summarised the answers and the respondent had the opportunity to correct, adjust or elaborate on the answers. Finally, in the focus groups the analysis of the interviews was presented and the focus groups were able to react and contribute to the answers.

\subsubsection{RELIABILITY}

According to Yin (2004), a strong theoretical framework is needed in order to clarify under which circumstances the specific case was studied. In the case studies for this research, all interviews were semi-structured. The interview questions are found in the Appendix. All interviews were recorded and later transcribed. This contributes to a structured way of collecting and storing data, which according to Yin (2004) can be a way of achieving reliability. 


\section{THEORETICAL FOUNDATION}

This chapter contains the theoretical foundation for this licentiate thesis.

\subsection{REMANUFACTURING}

Remanufacturing is one of the most effective ways of managing a product's end-of-life strategy (Steinhilper 1998, Sundin 2004,). According to several studies, remanufacturing is more environmentally sound than new production (Graedel and Allenby 2009, Sundin and Lee 2011). Remanufacturing is defined somewhat differently in the literature, ranging from more to less detailed; some of the definitions to be found are as follows:

"Remanufacturing is an industrial process whereby products referred to as cores are restored to useful life. During this process the core passes through a number of remanufacturing steps, e.g. inspection, disassembly, part replacement/refurbishment, cleaning, reassembly, and testing to ensure it meets the desired standards" (Sundin 2004).

Ijomah (2007) describes remanufacturing as a process of bringing used products to a "like-new" state with a warranty to match.

Steinhilper (1998) describes remanufacturing as the ultimate form of recycling, by manufacturing "good as new" products from used products. 
"Remanufacturing is the process of recapturing the value added to material when a product is remanufactured” (Charter and Gray 2008).

A generic remanufacturing process includes the following steps according to (Sundin 2004): inspection, disassembly, cleaning, reprocessing, reassembly, testing and storage. Remanufacturing thus enables products to remain in a cyclic loop (Seliger 2011).

Engaging in remanufacturing implies that there has to be a reverse logistics system in order for the used goods to return to the OEM or arrive at the independent remanufacturer (Sundin 2004). The success of a reverse logistics system also depends on the relationship between the company and the customer, which needs to be managed well (Östlin et al. 2008).

One strategy to apply when opting to cut costs in the remanufacturing process is to capture the value of information (Doyle et al. 2011). Efficient remanufacturing, where the cores can be remanufactured more than once, reduces energy consumption over the product life-cycle (Sundin and Lindahl 2008).

Decisions about the product take-back option need to be considered in the beginning of the design process in order to be efficient. Product take-back options include reuse, refurbishing and remanufacturing. The aim with product take-back is to recover as much as possible of the product and its parts, according to the end-of-life hierarchy (Sundin and Lee 2011). Remanufacturing is one of the most effective ways of managing a product's end-of-life strategy (Steinhilper 1998, Ke et al. 2011). According to several researchers, remanufacturing is more environmentally friendly than new production (Sundin \& Lee 2011).

Drivers for remanufacturing are according to (Östlin 2008) divided into three main categories, namely: ecological, economic, and policy-oriented. However, without the possibility of revenues there is no real incentive for a company to remanufacture (Ijomah et al. 2007).

The remanufacturing process is characterised by uncertainties related to the incoming cores (Lundmark et al. 2009) (Figure 10). The amount of incoming cores often fluctuates, however, and the condition of the incoming cores is hard to predict. Often, there is a lack of information about the product's life. Thus, the condition of the core, the time when it will arrive, the type of product it is and the reparations it has undergone are unknown to the remanufacturer. Even the brand of the incoming products can vary, and it is hard to predict what types of cores are going to arrive each day. In the remanufacturing process, typically information 


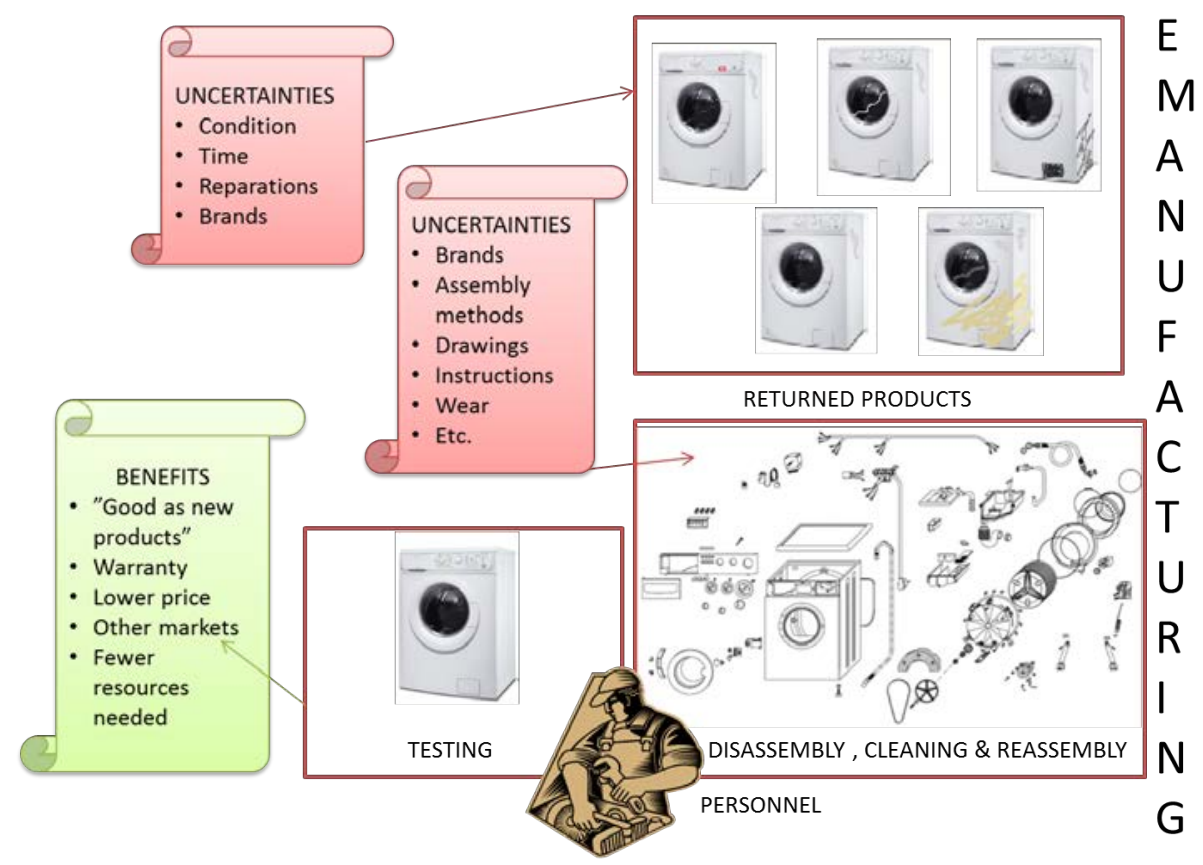

Figure 10. Some charachteristics of the often labour-intensive remanufacturing process

such as drawings and assembly methods would be useful for the remanufacturers. Before the product is disassembled there are also uncertainties regarding the wear of the components. The condition of the components will determine what operations they will need, if they can be reused after cleaning, and if they need reprocessing or have to be scrapped (Galbreth and Blackburn 2006). The remanufactured products are often sold at a lower price on other markets than the new products (Östlin 2008).

There are basically three types of remanufacturers in terms of their relation to the OEM (Östlin 2008):

- The OEM that remanufactures

- The contracted remanufacturer

- The independent remanufacturer

The OEM that produces new products as well as remanufactures their own products is able to keep control of their products and protect the brand. Another way to achieve that is to contract remanufacturers to provide the OEM with the service of remanufacturing. 
The third type is the independent remanufacturer that has no connection to the OEM; they remanufacture used products available on the market.

\subsubsection{DESIGN FOR REMANUFACTURING}

Design for remanufacture (DfRem) implies that the designers regard the product aspects important for remanufacture. Product properties that are specifically related to remanufacturing are: ease of identification, ease of verification, ease of access, ease of handling, ease of separation, ease of securing, ease of alignment, ease of stacking and wear resistance (Sundin 2004).

DfRem should be considered early on in the design process in order to be efficient (Hatcher et al. 2011a). DfRem is beneficial for the environment and also an opportunity for the company the increase their revenue (Chiodo et al. 2011, Kerr and Ryan 2001). However, there is little DfRem carried out in companies at present (Charter and Gray 2006, Hatcher et al. 2011a). In order for that to change, the business model of a company that wants to engage in DfRem needs to be adjusted accordingly (Gray and Charter 2008, Hatcher et al. 2011b).

For instance, remanufacturing would benefit from standardized products that are comprised of modules (Östlin 2008). The reuse of modules in closed loop product chains increases value (Krikke at al. 2004). Increasing the size and thickness of components would also help in prolonging the product's life (Mabee et al. 1999). Further, the possibility to upgrade products is beneficial for remanufacturing (Östlin et al. 2009).

It is interesting to observe that some assembly technologies are not suitable for disassembly, which might be necessary later in the product's life (Sundin \& Lindahl 2006). How to assemble a product's components are decisions made during the design phase of the product, and that is thus where decisions for suitable disassembly need to be taken (Figure 11).

Further, not all components may be remanufactured. Some have to be recycled, others scrapped while yet others might be reused. It is important to have a planned design process where the end-of-life options are considered, even on component level (Bufardi et al. 2004) 


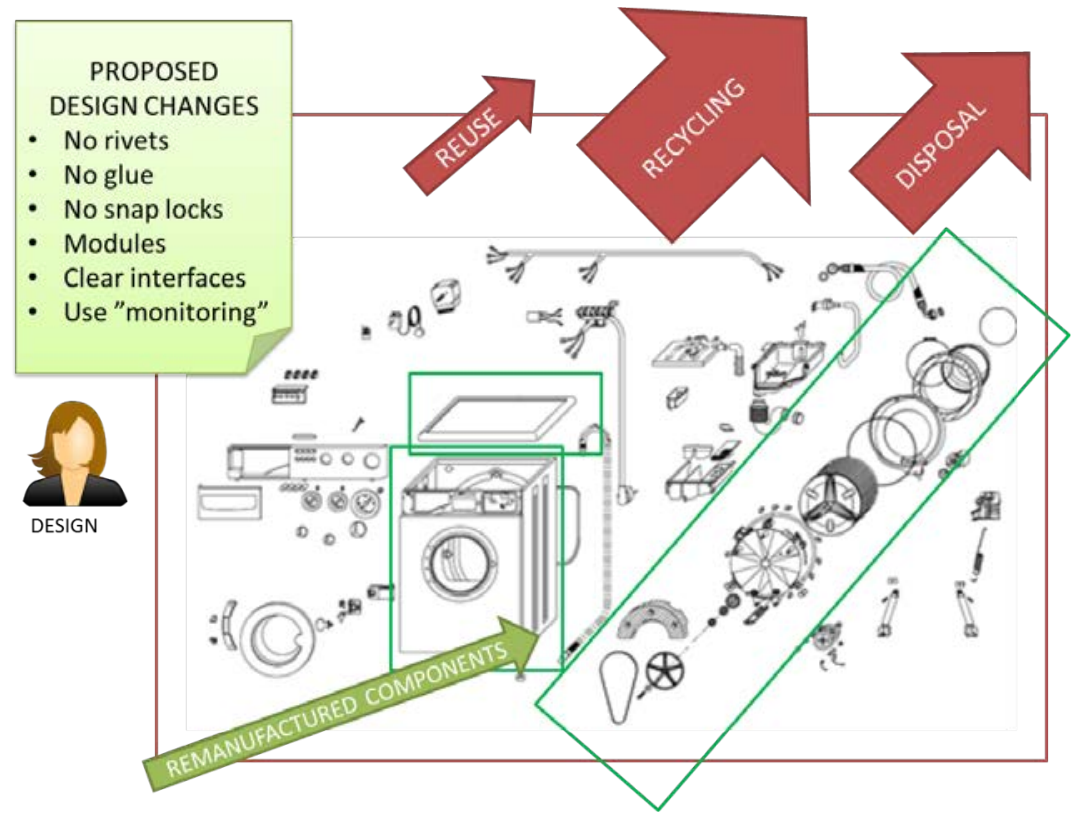

Figure 11. Examples of design for remanufacturing improvements that could be applied to this exemplified product..

\subsection{PRODUCT DESIGN FROM A LIFE-CYCLE PERSPECTIVE}

The different requirements of the different phases in a product's life-cycle are varied and many, and thus product development is not a simple activity. Product development, rather, is a complicated and sometimes even complex activity (Kurtz and Snowden 2003).

Although product development takes place during the design phase, it affects the whole chain of activities linked to a product's life-cycle (Doyle et al. 2011). If the decision makers at the producing company are considering the entire life-cycle, certain measures can be taken in the design phase. Therefore, the entire life-cycle needs to be considered early on in the product development process (Pigosso et al. 2010)

Decisions about product take-back options should preferably be considered as early as in the beginning of the design process, in order to be efficient (Loomba and Nakashima 2011). Product take-back options include reuse, refurbishing and remanufacturing. Product development, service and product take-back options are all related to the lifecycle of a generic product. Ultimately, the product should be adapted as to suit all of the 
product life-cycle phases such as manufacture, use, service, product take-back option and end-of-life option.

During the design phase the product's properties are determined. When a product is developed, customer data is a crucial part of the information gathered in the design phase (Ulrich and Eppinger 2008). Although adapting the product design according to the customers' demands in the use phase is important, the perspective of other life-cycle phases should not be overlooked. The different requirements of the different phases in a product's life-cycle are many; however, the overall environmental performance and competitiveness of a product over a lifetime should also be considered (Bovea and PérezBelis 2012, Umeda et al. 2000).

A generic product life-cycle contains the raw material phase, design phase, manufacturing phase, use phase and end-of-life phase. Traditionally, manufacturers view the product life-cycle as raw material, product design production, transport and sales. On the other hand, the customer typically would regard the life-cycle as beginning with the actual purchase, then transport, use and end-of-life. Naturally, these chains combined give the full picture of the product life-cycle (Japtag and Jonsson 2011). The company needs to consider the entire product life-cycle in order to increase efficiency throughout it (Pigosso et al. 2010). It is when companies engage in the product's entire life-cycle, and thus continue to create value for the customer, that they realize the possibilities of increased revenue (Figure 12).

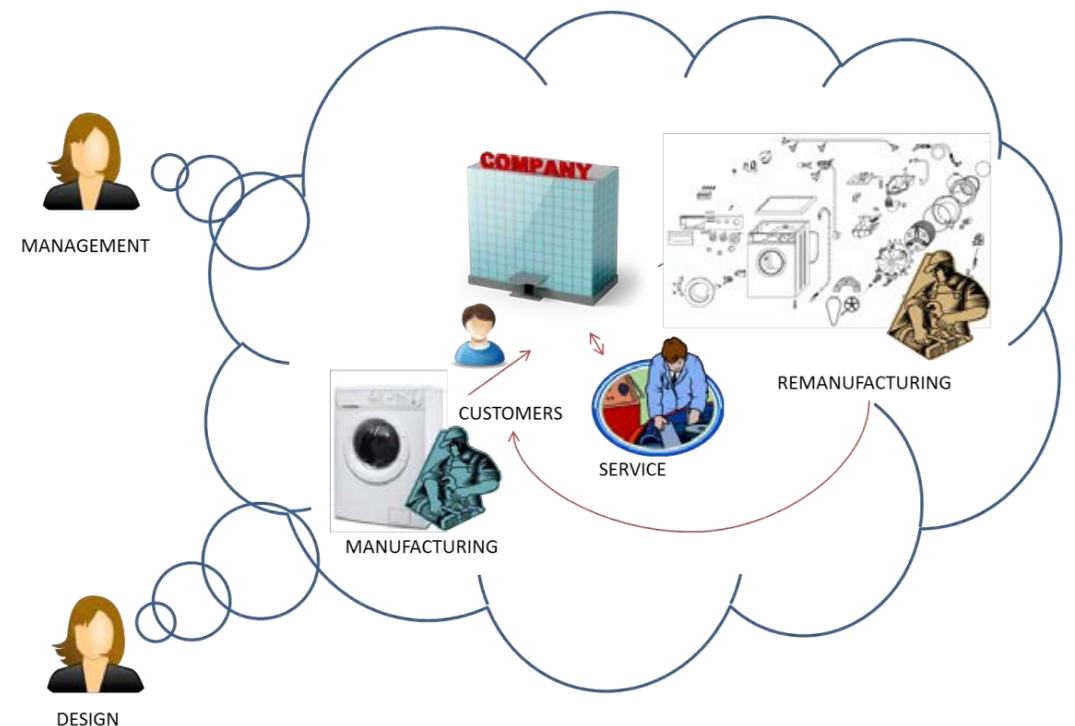

Figure 12. A product life-cycle perspective of managers as well as product designers is desirable. 


\subsection{PRODUCT LIFE-CYCLE INFORMATION FEEDBACK TO PRODUCT DESIGN}

Resent research shows that the information flow from remanufacture and service has impact on the design process (Lee et al. 2011, Doyle et al. 2011, Hatcher et al. 2011, Japtag and Johnsson 2011).

Feedback from the manufacturing phase, both subjective and objective, can improve the product's manufacturability (Molcho et al. 2008). Additionally, objective feedback of product use information to product development can facilitate improvement of future product generations Abramovici and Linder 2011, Fathi and Holland 2009).

Preferably, both subjective and objective data should be gathered throughout the product's life-cycle (Haider 2009, Zhang et al. 2012, Beck and Schornack 2005). The product's actual performance, which is measurable, as well as its perceived performance, which is non-measurable, are both factors which can affect perceived customer value. Condition monitoring is one way to achieve more objective data, rather than subjective readings from service technicians.

However, there is a need to balance all the incoming requirements and wishes as well as extracting the relevant information. The information flows have to be efficient and managed well. Thus, the information flows need to be designed and communication established all along the product life-cycle (Tukker and Jansen 2006). Information should be easy accessible for the right people at the right time and continuously updated.

\subsection{DESIGN FOR SERVICE}

Prolonging the product's useful life can be good from an environmental point of view (Sundin and Bras 2005, Maxwell and van der Vorst 2003). This can be achieved by providing different services during the use phase, as part of PSS (Tukker 2004). The product's design should allows for easy maintenance (Mabee et al. 1999). For instance, the product could be designed with standardized parts in modules based on platforms. This could facilitate both remanufacturing and service (Mabee et al. 1999, Chiodo et al. 2011). Service could extend the product's useful life through maintenance and, for instance, education directed at users on how to best use the product, which also can benefit the environment (Aurich et al.2006). Service is also an opportunity for the company to interact continuously with their customers, thus creating links between the customer/user and the manufacturer (Tukker 2004). 
Moreover, since service could extend a product's useful life through maintenance and e.g. education directed at users on how to best use the product, there are potential benefits for the environment to be gained (Aurich et al. 2006).

In order to facilitate forecasting of when a product is in need of service, modern ways of monitoring products from a distance could be efficient. As service offerings are increasingly common, the importance for the service selling companies to know the status of their machines, or being able to predict status based on for example used cycles, increases. Xerox is one of those companies that use this kind of technology. (Xerox 2012). 


\section{RESULTS}

The findings during the literature studies and the empirical studies have been presented in three consecutive papers. These findings are completed with further analysis in this chapter, and presented in the following sections.

\subsection{PRODUCT LIFE-CYCLE FEEDBACK TO PRODUCT DESIGN}

The design phase not only determines the properties of a product, but as a consequence also the performance of the product during its entire lifetime. Thus, the decisions made in the design phase concern the entire life-cycle. From the literature study presented in Paper I, the following motivations for further study of the product life-cycle information flows were identified: First, when PSS providers and remanufacturing companies or OEM original equipment manufacturers design their products, they need to consider how the product performs during the entire product life-cycle - instead of the traditional focus only on the use phase. Second, a life-cycle perspective is essential for sustainable product development. Third, contrary to the typical linear perspective where the producers' responsibilities stretch only to the use phase, the sustainable way is to include all of the life-cycle steps as well as the end-of-life.

Likewise, the overall environmental performance and competitiveness of a product over a lifetime should be considered. A product goes through different processes and is handled 
by many people during its life-cycle. Thus, there are multiple possibilities to gather feedback and receive information about how well the product performed during its lifetime. Such information could be useful when designing a product. Recent research indicates that the information flow from remanufacturing and service has an impact on the design process (e.g. Jagtap and Johnson (2011), Doyle et al. (2011), Hatcher et al. (2011b)). However, little design for remanufacturing is carried out in companies today (e.g. Charter and Gray (2008), Hatcher et al. (2011a)), which means that products are not often adapted for efficient remanufacturing. The idea, however, is that effective use of information feedback should lead to products better adapted for remanufacturing and service.

The result from the literature study presented in Paper I describes the character of the feedback from the different product life-cycle phases (Table 2).

The literature study identified different sources of information feedback, from the product life-cycle to design. Starting with manufacturing, feedback flows contain manufacturing process data where the product is evaluated on how well it is adapted for efficient manufacturing. Further, manufacturing personnel may have suggestions for improvement.

The next section consists of information feedback from the use and service phases back to product design, which naturally contains the customer's opinions of how well the product performed according to their demands and wishes. User evaluations are commonly used to improve products for the use phase, but there is however more information to be retrieved from this phase. For instance, condition monitoring could be used to supervise the product in use and see how it performs during its lifetime, and thus give the opportunity to for instance predict when service should be performed. Condition monitoring can also be used during service in order to get a obtain a snapshot of how the product performs and the condition of vital components. Further, there are other types of service process data, for instance when maintenance is performed; here, the product can be evaluated on how well it was adapted to efficient service, for instance how easy it was to change spare parts.

During the remanufacturing process, there are opportunities to evaluate how well the product was adapted to efficient remanufacturing. Product properties include for example whether the product is easy to disassemble in order to be cleaned and reassembled without damage. 
Table 2. Information feedback sources and characteristics, from Paper I.

\begin{tabular}{|c|c|c|c|}
\hline $\begin{array}{l}\text { Life-Cycle } \\
\text { Phase }\end{array}$ & $\begin{array}{l}\text { Information } \\
\text { Needed }\end{array}$ & Activities & References \\
\hline \multirow[t]{2}{*}{ Manufacturing } & $\begin{array}{l}\text { Manufacturing } \\
\text { process data }\end{array}$ & $\begin{array}{l}\text { Evaluating how well the product was } \\
\text { adapted for efficient production }\end{array}$ & Molcho et al. (2008), Baxter et al. (2009 \\
\hline & $\begin{array}{l}\text { Manufacturing } \\
\text { personnel data }\end{array}$ & Suggestions for improvement & $\begin{array}{l}\text { Molcho et al. (2008), } \\
\text { Baxter et al. (2009) }\end{array}$ \\
\hline \multirow[t]{4}{*}{$\begin{array}{l}\text { Use and } \\
\text { Service }\end{array}$} & Customer data & $\begin{array}{l}\text { Contrasting how the product } \\
\text { performed compared to expected }\end{array}$ & $\begin{array}{l}\text { Ulrich and Eppinger (2009), Zhang et al. } \\
\text { (2012) }\end{array}$ \\
\hline & $\begin{array}{l}\text { Condition } \\
\text { monitoring data }\end{array}$ & Input from product and service & $\begin{array}{l}\text { Fathi and Holland 2009, Abramovici } \\
\text { and Linder (2011), Dienst et al. (2011) }\end{array}$ \\
\hline & $\begin{array}{l}\text { Service process } \\
\text { data }\end{array}$ & $\begin{array}{l}\text { Evaluating how well the product was } \\
\text { adapted for efficient service }\end{array}$ & $\begin{array}{l}\text { Baxter et al. (2009), Fathi and Holland } \\
\text { (2009), Abramovici and Linder (2011), } \\
\text { Dienst et al. (2011), Japtag and Johnson } \\
\text { (2011) }\end{array}$ \\
\hline & $\begin{array}{l}\text { Service personnel } \\
\text { data }\end{array}$ & Suggestions for improvement & Baxter et al. (2009), Zhang et al. (2012) \\
\hline \multirow[t]{3}{*}{ End-of-Life } & $\begin{array}{l}\text { Remanufacturing } \\
\text { process data }\end{array}$ & $\begin{array}{l}\text { Evaluating how well the product was } \\
\text { adapted for efficient remanufacturing }\end{array}$ & $\begin{array}{l}\text { Doyle et al. (2011), Lee et al. (2011), } \\
\text { Hatcher et al. (2011), Zhang et al. } \\
\text { (2012) }\end{array}$ \\
\hline & $\begin{array}{l}\text { Remanufacturing } \\
\text { personnel data }\end{array}$ & Suggestions for improvement & Zhang et al. (2012) \\
\hline & $\begin{array}{l}\text { Wear on } \\
\text { components }\end{array}$ & $\begin{array}{l}\text { Evaluating how well the product was } \\
\text { adapted for its calculated life-cycle }\end{array}$ & $\begin{array}{l}\text { Fathi and Holland 2009, Abramovici } \\
\text { and Linder (2011), Dienst et al. (2011) }\end{array}$ \\
\hline
\end{tabular}

The remanufacturing process is commonly not automated but performed manually; thus, the remanufacturing personnel interact closely with the product and may have suggestions for improvement of the product design. Further, wear on components can supply feedback as to how well the product was adapted for its calculated life-cycle, or in the case of remanufacturing, multiple life-cycles.

The information feedback from all of these life-cycle phases should be balanced and available to the right people at the right time. The collected information should give a good view of the product life-cycle performance. The feedback can be divided into two major groups of information: objective and subjective.

As seen in Table 3, the sources of information feedback are both objective and subjective. The objective information can be in the form of graphs and measurements from e.g. condition monitoring, whereas the subjective data is based on opinions and estimations. Combined objective and subjective information captures how well the product was adapted for its life-cycle. 
Table 3. Sources of objective and subjective information feedback from the product life-cycle.

Sources of objective inform
Manufacturing process
Condition monitoring
Service process
Remanufacturing process
Wear on components

\section{Sources of objective information}

Wear on components

\section{Sources of subjective information}

Manufacturing personnel

Customer data

Service personnel

Remanufacturing personnel

Objective feedback is increasingly sought after, and often through technology development functions such as condition monitoring. With condition monitoring, it is possible to get data on how certain vital parts of a product have performed over time with built-in technology. It is also possible to use external handheld devices and make momentary condition monitoring as part of a service or remanufacturing inspection.

\subsection{REMANUFACTURING CHARACTERISTICS OF THE CASES STUDIED}

Papers II and III are based on case studies. In Paper II, the initial pilot study is presented. That case study is later referred to as Case C in Paper III, which also contains the results from Cases A and B. Since the case studies presented in Papers II and III focus on the same subject, they are compared and contrasted here. Table 4 shows some properties of the cases. The companies have experience in remanufacturing, however, the acknowledgement of that remanufacturing business varies between the cases.

Table 4. Characteristics of the case companies presented in Paper II and III.

\begin{tabular}{|l|l|l|l|}
\hline Variable & Case A & Case B & Case C \\
\hline Company size & Large & Large & Large \\
\hline Sector & Machines & Furniture & Machines \\
\hline Product complexity & Medium & Low & High \\
\hline Remanufacturing for & 10 years & 20 years & 10 years \\
\hline $\begin{array}{l}\text { Remanufacturing business } \\
\text { compared to manufacturing }\end{array}$ & Medium & Minor & Minor \\
\hline
\end{tabular}


In Case $\mathrm{A}$, the remanufacturing business stems from the flow of incoming rental machines (Figure 13), and that business has expanded with the increasing demand for rental machines. Furthermore, the remanufacturing business is now counted on as a reliable source of income. In fact, during the recession that Europe recently experienced, the sales of remanufactured machines increased, contrary to the sales of newly manufactured machines. Although remanufacturing is an increasingly important part of the OEMs' activities in Case A, there is no design for remanufacturing. In fact, the remanufacturer has noticed changes in the machines' design that have a negative impact on the remanufacturing process. For instance, there are now more parts in plastic which cannot be remanufactured but need to be replaced.

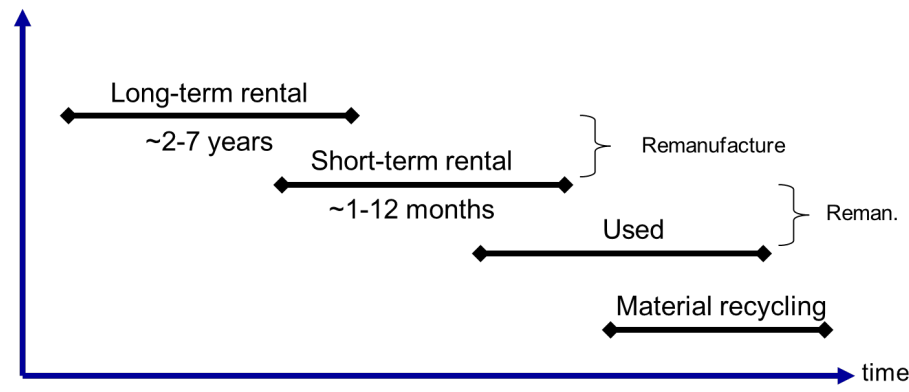

Figure 13. The remanufacturing process in Case A is linked to the rental schemes. Remanufacturing thus extend the use period for those machines.

The company in Case B has been remanufacturing exhibit products and warranty goods for many years. However, recycling is the most common end-of-life option for the used products (Figure 14). Albeit a steadily growing business, the remanufactured products are not marketed. The OEM considers the remanufactured products as competing with the newly produced products, and thus the word about the business is only spread by word of mouth. However, the OEM in Case B has a growing interest in design for disassembly, since they are more and more interested in increasing the recyclability of their products. They also want to increase efforts to design their products in modules for improved serviceability. Both these design efforts are potentially beneficial from a remanufacturing perspective since it e.g. facilitates the separation of parts. Furthermore, the newly manufactured products are mostly sold to large companies or organizations, whereas the remanufactured products are sold to small and medium-sized companies (SMEs), or even to private persons (B2C). Thus, it appears that the products could be sold on different markets, even with an expanded remanufacturing business. 


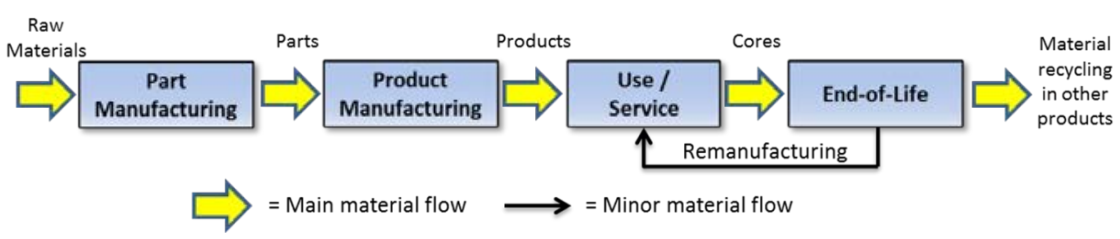

Figure 14 The remanufacturing scheme in Case B. Remanufacturing plays only a minor part in the value chain. Material recycling is the most commonly applied end-of-life option.

In Case $\mathrm{C}$ the remanufacturing business has struggled with its reputation, but as the business is expanding, so is the acceptance for the business internally at the OEM. The remanufacturing business is however still minor, although expanding with more global sites. The remanufacturing is performed by contracted remanufacturers. There is no design for remanufacturing today; however, the machines are increasingly designed in modules as design for service is becoming a priority for the company. Case company $\mathrm{C}$ also experienced an increase in demand for remanufactured products during the recession in 2008. However, their remanufacturing system (Figure 15) is such that they source the cores upon order from a customer. The core is then delivered to a contracted remanufacturer where it is remanufactured. Thus, there are no remanufactured machines in stock since they are both large and expensive. Consequently, the OEM has to make efforts to identify appropriate machines for remanufacture and the lead time from order to delivery can be quite long.

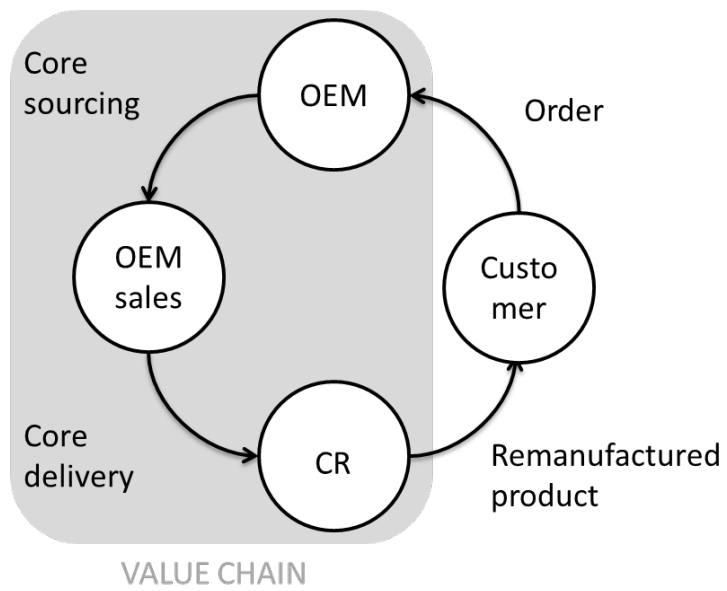

Figure 15. A schematic picture of the remanufacturing system in case $\mathrm{C}(\mathrm{OEM}=$ Original Equipment Manufacturer, $\mathrm{CR}=$ Contracted Remanufacturer). 


\subsection{PRODUCT LIFE-CYCLE INFORMATION FLOWS RELATED TO REMANUFACTURING}

In the initial literature study presented in Paper I, information feedback was explored. When planning for the case studies to follow, mapping of the information feedback flows was one of the aims. However, the information feed forward from product development to the other selected stakeholders in the product life-cycle was also explored. Information feed forward from design is relevant if efficiency and assistance of the processes in manufacturing, service and remanufacturing is a concern. Information such as drawings should be available and up-to-date. Thus, investigation of the information feed forward flows was also included in the case study design.

Although the main research interest is the information flows to and from remanufacturing, the outcome of only studying those information flows was deemed hard to relate to. Thus, in order to be able to compare how remanufacturing is included in the information exchange, the information flows between the design, manufacturing, service and remanufacturing departments were investigated.

The information flows in Cases A to $\mathrm{C}$ are illustrated in Figures 16-18. The arrows represent the information flows while the thickness indicates the amount of information provided. The information flows were illustrated upon analysis of the interviews in the case companies. Later, the figures were presented to the case companies in a workshop where they had the opportunity to provide feedback on the results.

In Case A the OEM is divided into two organisations, the producer and the sales organisation (Figure 16). Remanufacturing is included in the sales organisation. Remanufacturing receives some information, such as the service instructions, technical support and some training, together with service technicians. The service technicians seldom inform remanufacturing about the status of the machines that they receive. Whether or not they receive such information depends on the individual service technician, and not on an established system for information exchange. Further, remanufacturing has access to some of the drawings, but not all since the machines are manufactured by different units within the global organisation. Remanufacturing reports, but rarely to manufacturing concerning frequent faults.

Remanufacturing is regarded by design as a minor part of the organisation, based foremost on its small share of the total turnover. On one hand, design does not see the potential benefits of involving remanufacturing to a greater extent in the overall 


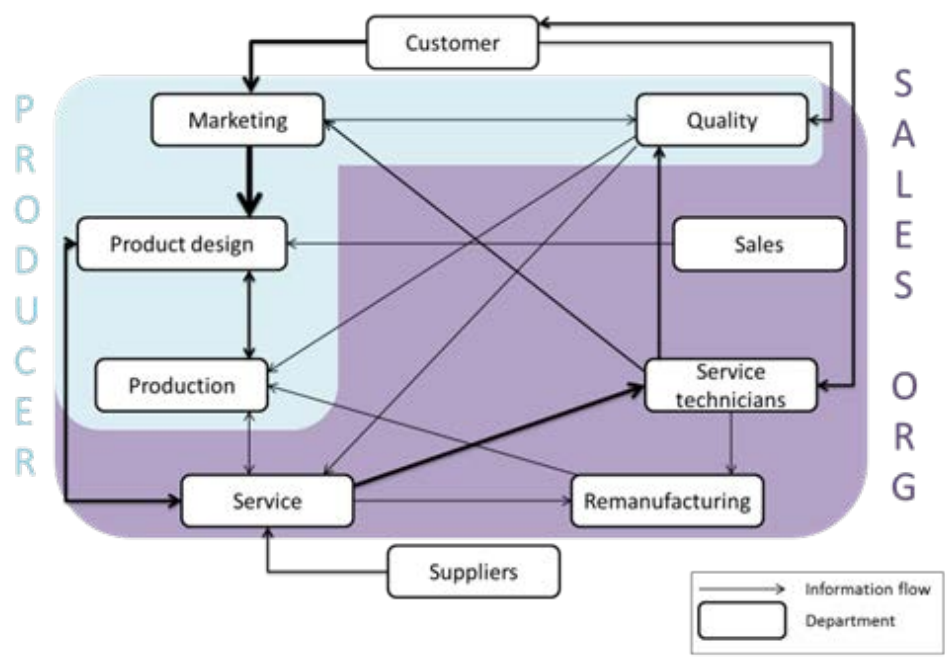

Figure 16. Information flows in Case A as presented in Paper III.

information exchange. On the other hand, remanufacturing does not see a need for more information at present. All the same, there is a lack of knowledge of the remanufacturing process and its conditions. Furthermore, there is no established channel for feedback from remanufacturing to design, and no arena where the two departments meet.

In Case B, the OEM designs all the products and produces half of them in-house, while the rest are delivered by suppliers. Remanufacturing is excluded from the information flows (Figure 17). This should be seen in light of the OEM regarding the remanufacturing side business as competing with the sales of new products. The remanufactured products are old exhibit products, returned goods and warranty claims. The remanufactured products are not actively marketed, and thus sold foremost on the local market to small and medium-sized companies.

The company profiles itself with high-quality products that are often sold with a service package. The products are robust and their expected lifetime is twenty years. Recent changes in the market, however, have led to a shorter use period of about five to seven years. There is thus potential for the OEM to explore expanding their remanufacturing business. 


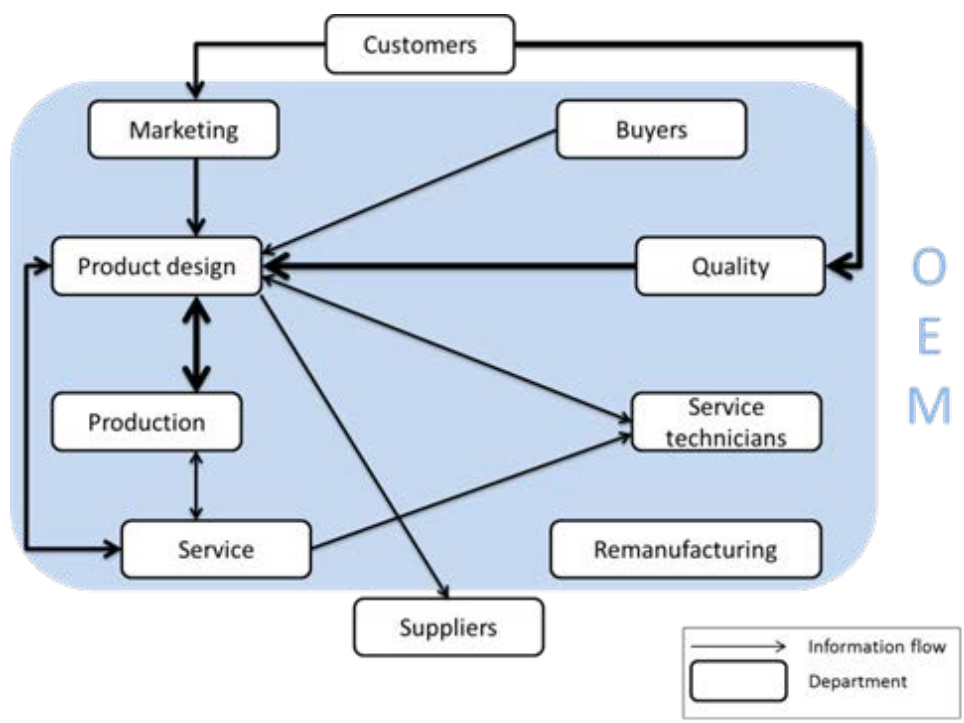

Figure 17. Information flows in Case B as presented in Paper III.

In Case C (Figure 18), the OEM designs the products that are produced by suppliers. The remanufacturing is done by contracted remanufacturers in a few selected global sites. The contracted remanufacturer in this study had established a good relationship with the OEM over the years, and as a consequence had recently gained access to a database where drawings and manuals are stored. Thus, design, service and the contracted remanufacturer all have access to the database and are able to receive for instance information about updates immediately. Remanufacturing seldom provides any feedback to design; it has happened on only a few occasions over the years that they have given suggestions for further improvement of the product design. Such information is however not routinely or systematically asked for at the design departments. 


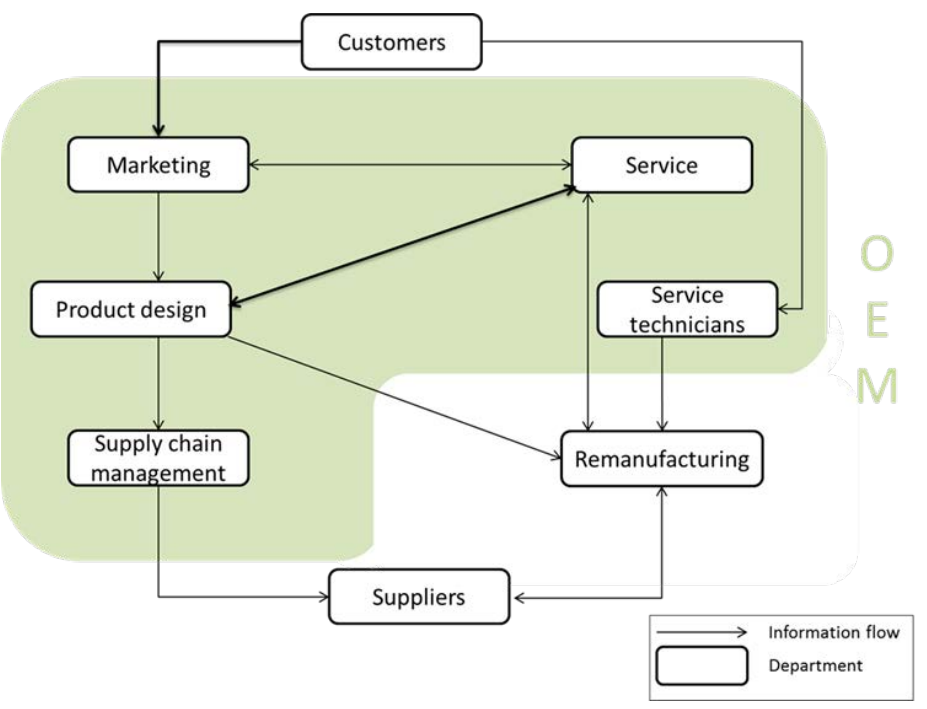

Figure 18. Information flows in Case C presented in Paper II.

\subsection{PRODUCT LIFE-CYCLE FEEDBACK TO PRODUCT DESIGN IN THE INDUSTRIAL CASES}

Upon analysis of the three Cases A, B and C, the information feedback flows were identified and weighted. The feedback flows are illustrated in Table 5. No entry in the table means no feedback, whereas one " $\mathrm{X}$ " indicates some feedback occurrence and "XXX" plenty of feedback provided from that source to design. 
Table 5. Information feedback frequency in the case companies A-C as presented in Paper II and III.

\begin{tabular}{|c|c|c|c|c|c|}
\hline $\begin{array}{l}\text { Life-Cycle } \\
\text { Phase }\end{array}$ & $\begin{array}{l}\text { Information } \\
\text { Needed }\end{array}$ & Activities & $\begin{array}{c}\text { Case } \\
\text { Company A }\end{array}$ & $\begin{array}{c}\text { Case } \\
\text { Company B }\end{array}$ & $\begin{array}{c}\text { Case } \\
\text { Company C }\end{array}$ \\
\hline \multirow[t]{2}{*}{ Manufacturing } & $\begin{array}{l}\text { Manufacturing } \\
\text { process data }\end{array}$ & $\begin{array}{l}\text { Evaluating how well the product was } \\
\text { adapted for efficient production }\end{array}$ & $x$ & $x X$ & \\
\hline & $\begin{array}{l}\text { Manufacturing } \\
\text { personnel data }\end{array}$ & Suggestions for improvement & $x$ & $x$ & \\
\hline \multirow[t]{4}{*}{$\begin{array}{l}\text { Use and } \\
\text { Service }\end{array}$} & Customer data & $\begin{array}{l}\text { Contrasting how the product } \\
\text { performed compared to expected }\end{array}$ & $\mathrm{XX}$ & $\mathrm{XXX}$ & $x X$ \\
\hline & $\begin{array}{l}\text { Condition } \\
\text { monitoring data }\end{array}$ & Input from product and service & & & $\mathrm{x}$ \\
\hline & $\begin{array}{l}\text { Service process } \\
\text { data }\end{array}$ & $\begin{array}{l}\text { Evaluating how well the product was } \\
\text { adapted for efficient service }\end{array}$ & $\mathrm{XXX}$ & $x x$ & $\mathrm{XXX}$ \\
\hline & $\begin{array}{l}\text { Service personnel } \\
\text { data }\end{array}$ & Suggestions for improvement & $x x$ & $\mathrm{x}$ & $x X$ \\
\hline \multirow[t]{3}{*}{ End-of-Life } & $\begin{array}{l}\text { Remanufacturing } \\
\text { process data }\end{array}$ & $\begin{array}{l}\text { Evaluating how well the product was } \\
\text { adapted for efficient remanufacturing }\end{array}$ & & & \\
\hline & $\begin{array}{l}\text { Remanufacturing } \\
\text { personnel data }\end{array}$ & Suggestions for improvement & & & $\mathrm{x}$ \\
\hline & $\begin{array}{l}\text { Wear on } \\
\text { components }\end{array}$ & $\begin{array}{l}\text { Evaluating how well the product was } \\
\text { adapted for its calculated life-cycle }\end{array}$ & & & \\
\hline
\end{tabular}

As seen in the Table 5, there is no feedback from remanufacturing back to design in most of the cases studied. In Case $\mathrm{C}$, the contracted remanufacturer stated that on rare occasions it would provide design with some feedback on how to further improve the product design. That information was initiated by the contracted remanufacturer, and not asked for at the design department. Feedback from customers is frequently provided, in accordance with the findings of the literature study. Feedback from service is also frequent. The lack of feedback from manufacturing in Case $\mathrm{C}$ might relate to the structure of the value chain, as suppliers outside of the OEM manufacture the machines. 


\section{DisCUSSION AND CONCLUSIONS}

This chapter is dedicated to discussions and conclusions based on the previous chapters in the thesis. The chapter continues with the research's relationship to other research projects and the linkage to the remanufacturing industry. The chapter continues with the conclusion, which contains answers to the research questions presented in Chapter 1, and ends with suggestions for future research.

\subsection{DISCUSSION}

Preferably, the entire life-cycle of a product is considered in the design phase. It is only when the entire product life-cycle and alternative end-of-life options for the product and its individual components are considered that true sustainable responsibility can be taken from the producing companies. Whilst design is vital for the performance of the product over its lifetime, the designers cannot see the product's performance in each phase of the product life-cycle. Thus, is necessary for the product designer to have access to information feedback from the different phases of the product life-cycle. On the other hand, the designers may have information to provide to the product life-cycle phases. Thus, it is important to establish communication and information flows throughout the product life-cycle. 
However, there is not only a need to balance the information streaming from manufacturing and users, but also from remanufacturing and service. Much information has to be processed and handled in the design phase, and priorities have to be made. There is a need to know, for example, what information is required, how it should be retrieved throughout the product's entire life-cycle, and how it should be presented. These information flows have to be managed in order for the right information to reach the right people at the right time.

Optimally, information feedback from remanufacturing to the design phase could lead to products better adapted for remanufacturing. Products that are for instance easier to disassemble and reassemble would lead to a more efficient remanufacturing process and thus a gain for the OEM. One example of possible information flow is condition monitoring of goods from a distance. By monitoring the performance of the product continuously, forecasting when service is needed could be more accurate. Further, inspection in the remanufacturing phase could be facilitated if information about the condition that the cores are expected to be in when they arrive is known beforehand.

There are opportunities to establish information feedback flows from remanufacturing to product design. At present, there appears to be a need to raise awareness within the value chain of the remanufacturing process and its requirements, both at a management level and in the design phase. One possible approach is to inform those in the value chain about design for remanufacturing, in order to increase knowledge about remanufacturing in general in the design phase. Another is to include remanufacturing in the information flows, particularly information feedback to product design, to communicate design requirements for the specific remanufacturing processes. However, in order to make such changes, business decisions and company attitudes towards remanufacturing need to be altered.

\subsubsection{Methodology DisCuSSION}

The literature study was not an extensive literature study. The initial literature study identified feedback sources from the predefined phases manufacturing, use/service and remanufacturing. It was difficult to identify sources regarding information feedback from remanufacturing to design. It may be that more sources had been found using other search words and/or databases. However, product life-cycle information appears not to be well explored within the research field of remanufacturing. Further, several sources pointed out that little design for remanufacturing is applied when designing products.

The cases presented in this licentiate thesis are quite alike in terms of size, and none of them focus on remanufacturing equally much as manufacturing. However, the remanufacturing part of the business has expanded over the years in all the cases. 
Remanufacturing in Case $\mathrm{A}$ and $\mathrm{C}$ has access to some information from the other phases in the product life-cycle that can facilitate the remanufacturing process. In the all the cases, the understanding of the particular needs of the remanufacturing process appears to be low. Contrary to the common view, remanufacturing differs from for instance service, particularly because the remanufacturing process involves a full disassembly of the cores. The understanding of remanufacturing may vary between individuals and groups within the organization. However, in the cases studied there are no established channels for remanufacturing to provide feedback to design and no design for remanufacturing.

The result presented in this licentiate thesis has been confirmed through workshops where representatives from the different product life-cycle phases have been represented and thus given the opportunity to confirm or disconfirm the results. It was also an opportunity for the involved departments to come together and get a picture, however not complete, of the current information flows in the product life-cycle.

\subsection{CONCLUSIONS}

The research questions presented in the introduction are answered in this section:

RQ 1 What type of information is there to be fed back to product development from the product life-cycle phases of manufacturing, use/service, and remanufacturing?

The literature study presented in Paper I and in Section 4.1 identified the following sources of feedback from the product life-cycle:

- Manufacturing process data: Suggestions for improvement

- Manufacturing personnel data: Evaluating how well the product was adapted to efficient manufacturing

- Customer data:

Contrasting how the product performed compared to that expected

- Conditioning monitoring data: Input from product and service

- Service process data:

Evaluating how well the product was adapted to efficient service

- Service personnel data: Suggestions for improvement

- Remanufacturing process data: Evaluating how well the product was adapted to efficient remanufacturing 
- Remanufacturing personnel data:

Suggestions for improvement

- Wear on components:

Evaluating how well the product was adapted for its calculated life-cycle

The often manual remanufacturing process provides opportunities for feedback to product design, since the products are disassembled and the components cleaned in this phase of the product's life. Feedback such as suggestions for improvement from remanufacturing personnel, process data, and data about wear on components could help to improve the design of the next generation of products. Further, design changes could lead to a more efficient remanufacturing process.

RQ 2 How is information transferred to and from remanufacturing and the product life-cycle phases of design, manufacturing, and service?

In Papers II and III and in Sections 4.3 and 4.4 the following conclusions were presented:

Case A:

- In design, most focus is on the use phase, including feedback from customers and service.

- Remanufacturing receives some information such as drawings from design, but has no channel for providing feedback.

Case B:

- The design focus is on manufacturing and service; design for remanufacturing is not considered.

- Remanufacturing is not included in the information flows, as remanufacturing is regarded as competing with the OEM.

Case C:

- Feedback is highly valued from customers and service, but feedback from the contracted remanufacturers is not routinely gathered.

- Design for Remanufacturing is not carried out.

- The structure of the value stream appears to be a hindrance for full information exchange.

Information is transferred via databases, physical manuals and documents in the value chains. The cases presented in this licentiate thesis fail to explore the full potential of remanufacturing feedback to product design. All in all, remanufacturing is not 
sufficiently included in the information flows of the product life-cycle. Additionally, design for remanufacturing is not applied in any of the cases.

\subsection{CONTRIBUTION TO ACADEMIA}

- List of possible feedback sources to product design from the product life-cycle including remanufacturing.

- Analysis of remanufacturing's inclusion in the current information exchange in the product life-cycle via case studies.

- Identification of lack of feedback from remanufacturing to product development in the cases studied.

\subsection{CONTRIBUTION TO INDUSTRY}

- A mapping of the information flows within value chains that remanufacture.

- A presentation of possible information feedback flows in the product life-cycle.

- A presentation of challenges and opportunities regarding involvement of remanufacturing in the information exchange.

\subsection{FUTURE RESEARCH}

The research planned for the future consists primarily of prescriptive research studies of how companies can include design for remanufacturing in the design process. This is intended to be based on information feedback from the remanufacturers, and thus channels and systems for providing such feedback need to be explored. Further, the design processes needs to be investigated in order to understand how design criteria are included and balanced. 


\section{REFERENCES}

This chapter contain the references used in this thesis. 
ABRAMOVICI, M. and LINDNER, A., 2011. Providing product use knowledge for the design of improved product generations. CIRP Annals - Manufacturing Technology, 60(1), pp. 211214.

AURICH, J.C., FUCHS, C. and WAGENKNECHT, C., 2006. Life cycle oriented design of technical Product-Service Systems. Journal of Cleaner Production, 14(17), pp. 1480-1494.

BAXTER, D., ROY, R., DOULTSINOU, A., GAO, J. and KALTA, M., 2009. A knowledge management framework to support product-service systems design. International Journal of Computer Integrated Manufacturing, 22(12), pp. 1173-1188.

BECK, C.E., and SCHORNACK, G.R., 2005. A Systems Model for Knowledge Management: A Rhetorical Heuristic Process, System Sciences, 2005. HICSS '05. Proceedings of the 38th Annual Hawaii International Conference on 2005, pp. 242c-248c

BLESSING, L.T.M. and CHAKRABARTI, A., 2009. DRM, a Design Research Methodology. SpringerVerlag, London, UK.

BOVEA, M. D., and V. PÉRES-BELIS. 2012. A taxonomy of ecodesign tools for integrating environmental requirements into the product design process. Journal of Cleaner Production 20, (1): pp. 61-71.

BUFARDI, A., GHEORGHE, R., KIRITSIS D., and XIROUCHAKIS, P., 2004. Multicriteriadecision-aid approach for product end-of-life alternative selection, International Journal of Production Research, 42:16, pp. 3139-3157

CHARTER, M. and GRAY, C., 2008. Remanufacturing and product design. International Journal of Product Development, 6(3-4), pp. 375-392.

CHIODO, J., GRAY, C, and JONES, D., 2011. Design for Remanufacture, Recycling and Reuse, Proceedings of the 1st International Conference on Remanufacturing, pp. 277-283

DIENST, S., FATHI, M., ABRAMOVICI, M. and LINDNER, A., 2011. A conceptual data management model of a feedback assistance system to support product improvement, Systems, Man, and Cybernetics (SMC), 2011 IEEE International Conference on 2011, pp. 446-451.

DOYLE, K., IJOMAH, W. and ANTONY, J., 2011. Deciding End of Life Strategy during Product Design, Proceedings of the 1st International Conference on Remanufacturing, pp.255-261

EVANCE, D. and KOWANKO, I., 2000. Literature reviews: evolution of a research methodology. The Australian Journal of Advanced Nursing : a Quarterly Publication of the Royal Australian Nursing Federation 2000, 18(2), pp. 33-38.

FATHI, M. and HOLLAND, A. (2009). Knowledge-based feedback integration to facilitate sustainable product innovation, ETFA 2009 - 2009 IEEE Conference on Emerging Technologies and Factory Automation 2009.

FUKUSHIGE, S., KUNII, E., YAMAMOTO, K. and UMEDA,Y. 2011. A Design Support System for Scenario-Based Lifecycle Design. ASME International Design Engineering Technical Conferences and Computers and Information in Engineering Conference Volume 9: 23rd; pp. 919-927

GALBRETH, M.R., and BLACKBURN J. D., 2006. Optimal Acquisition and Sorting Policies for Remanufacturing Journal of Production and operations management . Vol. 15, No. 3, pp. 384-392

GRAEDEL, T.E. and ALLENBY, B. R. 2009 Industrial Ecology, Prentice Hall, London. 
GUTOWSKI, T., SAHNI, S., BOUSTANI, A. and GRAVES, S.C, 2011. Remanufacturing and Energy Savings Environ. Sci. Technol., 2011, 45 (10), pp. 4540-4547.

HAIDER, A., 2009. Evaluation of information systems supporting asset lifecycle management, SpringerVerlag Berlin Hiedelberg, pp. 906-917.

HART, C., 1998. Doing a literature review-releasing the Social sience research imagination. SAGE Publications Ltd, London, UK.

HATCHER, G.D., IJOMAH, W.L. and WINDMILL, J.F.C., 2011. Design for remanufacture: A literature review and future research needs. Journal of Cleaner Production, 19(17-18), pp. 2004-2014.

HATCHER, G. D., IJOMAH, W. and WINDMILL, J., 2011, Design for Remanufacture in an OEMRemanufacturer Organization, Proceedings of the 1st International Conference on Remanufacturing, pp. 286-292

IJOMAH, W.L., MCMAHON, C. and CHILDE, S., 2004. Remanufacturing - A key strategy for sustainable development, Design and Manufacture for Sustainable Development 2004, pp. 51-63.

IJOMAH, W.L., MCMAHON, C.A., HAMMOND, G.P. and NEWMAN, S.T., 2007. Development of design forremanufacturing guidelines to support sustainable manufacturing. Robotics and Computer-Integrated Manufacturing, 23(6), pp. 712-719.

IPCC- Intergovernmental Panel on Climate Change 2013. Accessed 2014-02-04 http://www.climatechange2013.org/images/report/WG1AR5_SPM_FINAL.pdf

JAPTAG, S. and JOHNSON, A. 2011. In-service information required by engineering designers, Research in Engineering Design, pp. 1-15.

KE, Q., ZHANG, H., LIU, G. and LI, B., 2011. Remanufacturing engineering literature overview and future research needs, Glocalized Solutions for Sustainability in Manufacturing Proceedings of the $18^{\text {th }}$ CIRP International Conference on Life Cycle Engineering 2011, pp. 437-442.

KERR, W. and RYAN, C., 2001. Eco-efficiency gains from remanufacturing: A case study of photocopier remanufacturing at Fuji Xerox Australia. Journal of Cleaner Production, 9(1), pp. 75-81.

KRIKKE, H., LE BLANC, I. and VAN DE VELDE, S., 2004, Product Modularity and the Design of Closed-Loop Supply Chains, California Management Review Vol 46 No 2, pp. 23-39.

LEE, H.M., SUNDIN, E. and NASR, N. 2011 Review of End-of-Life Management Issues in Sustainable Electronic Products, Proceedings of The 9th Global Conference on Sustainable Manufacturing, Saint Petersburg, Russia, September 28-30, pp. 121-131.

LEEDY, P.D. and ORMROD, J.E., 2010. Practical Research - planning and design. Nineth edition. Pearson Education International, Boston, US.

LINDAHL, M., 2006. Engineering designers' experience of design for environment methods and tools Requirement definitions from an interview study. Journal of Cleaner Production, 14(5), pp. 487-496.

LOOMBA, A.P.S and NAKASHIMA K., 2011. Sustainable Ecodesign Mapping of End-of-Life Strategies for Improved Products/Processes Management. Proceedings of EcoDesign 2011 International Symposium, pp. 696-699.

LUNDMARK, P., SUNDIN, E. and BJÖRKMAN M, 2009. Industrial challenges within the remanufacturing system. Proceedings of Swedish Production Symposium. Stockholm 2009, pp. 132-139. 
MABEE, D.G., BOMMER, M. and KEAT, W.D. 1999. Design charts for remanufacturing assessment. Journal of Manufacturing Systems, 18(5), pp. 358-366.

MAXWELL, D. and VAN DER VORST, R., 2003. Developing sustainable products and services. Journal of Cleaner Production, 11(8), pp. 883-895.

MOLCHO, G., ZIPORI, Y., SCHNEOR, R., ROSEN, O., GOLDSTEIN, D. and SHPITALNI, M. 2008. Computer aided manufacturability analysis: Closing the knowledge gap between the designer and the manufacturer. CIRP Annals - Manufacturing Technology, 57(1), pp. 153158.

PATTON, M.Q. 2002. Qualitative Research and Evaluation Methods. Thousand Oaks, CA: Sage Publications, Thousand Oaks, US.

PIGOSSO, D.C.A., ZANETTE, E.T., FILHO, A.G., OMETTO, A.R. and ROZENFELD, H., 2010. Ecodesign methods focused on remanufacturing. Journal of Cleaner Production, 18(1), pp. 21-31.

SELIGER, G., 2011. Sustainability engineering by Product-Service Systems, 18th CIRP International Conference on Life Cycle Engineering: Glocalized Solutions for Sustainability in Manufacturing, May 2-4, pp. 22-28.

STEINHILPER, R. 1998. Remanufacturing, The Ultimate Form of Recycling, Fraunhofer IRB Verlag, Stuttgart.

SUNDIN, E. 2004. Product and process design for successful remanufacturing, Linköping Studies in Science and Technology, Dissertation No 906 Linköping University, Linköping, Sweden.

SUNDIN, E. and LEE H.M., 2011, In what way is remanufacturing good for the environment?, Proceedings of the $7^{\text {th }}$ International Symposium on Environmentally Conscious Design and Inverse Manufacturing (EcoDesign-11) November 30 - December 3, Kyoto, Japan, pp 551556.

SUNDIN, E. and BRAS, B., 2005. Making functional sales environmentally and economically beneficial through product remanufacturing. Journal of Cleaner Production, 13(9), pp. 913-925.

SUNDIN, E. and LINDAHL, M., 2008. Rethinking Product Design for Remanufacturing to Facilitate Integrated Product Service Offerings, Proceedings of IEEE International Symposium on Electronics and the Environment (IEEE-08), San Francisco, USA.SUNDIN, E., TANG, O. and MÅRTÉN, E. 2005. The Swedish Remanufacturing Industry - An Overview of Present Status and Future Potential, Proceedings of the 12th CIRP Life Cycle Engineering Seminar, Paper BM4 on the LCE-05 CD, Laboratoire 3S, Grenoble, France, April 3-5.

SUNDIN, E. and ÖSTLIN, J. 2005 Case study of Three Toner Cartridge Remanufactures, Proceedings of EcoDesign-05, $4^{\text {th }}$ International Symposium on Environmentally Conscious Design and Inverse Manufacturing, Tokyo, Japan, 12-14 December.

TUKKER, A., 2004. Eight types of product-service system: Eight ways to sustainability? Experiences from suspronet. Business Strategy and the Environment, 13(4), pp. 246-260.

TUKKER, A. and JANSEN, B., 2006. Environmental impacts of products: A detailed review of studies. Journal of Industrial Ecology, 10(3), pp. 159-182.

ULRICH, K.T. and EPPINGER, S.D., 2009. Product design and development. MC Graw Hill International Edition, US.

UMEDA, Y., NONOMURA, A. and TOMIYAMA, T., 2000. Study on life-cycle design for the post massproduction paradigm. Artificial Intelligence for Engineering Design, Analysis and Manufacturing: AIEDAM, 14(2), pp. 149-161. 
WILLIAMSON, K., 2002. Research methods for students, academics and professionals - information management and systems. Second edition. Center of Information Studies, Quick print, Wagga Waga, Australia.

XEROX, 2012. http://www.xerox.com/digital-printing/printing-press/xerox-igen3-110-90/printermanagement/enus.html, accessed 2014-05-09.

XIAOYAN, W. 2012. Research on design management based on green remanufacturing engineering. Systems Engineering Procedia, 4(0), pp. 448-454.

YIN, R.K. 2004 Case Study Research: Design and Methods, fourth edition. SAGE Publications, Inc., Thousand Oaks, CA, USA.

ZHANG, D., HU, D., XU, Y. and ZHANG, H., 2012. A framework for design knowledge management and reuse for Product-Service Systems in construction machinery industry. Computers in Industry, 63(4), pp. 328-337.

ÖSTLIN, J. 2008. On Remanufacturing Systems, Analyzing and Managing Material Flows and Remanufacturing Processes. Linköping Studies in Science and Technology, Dissertation No 1192, Linköping University, Linköping, Sweden.

ÖSTLIN, J., SUNDIN, E. and BJÖRKMAN, M. 2008a. Business Drivers for Remanufacturing, Proceedings of $15^{\text {th }}$ CIRP International Conference on Life Cycle Engineering. The University of New South Wales, Sydney, Australia.

ÖSTLIN, J., SUNDIN E. and BJÖRKMAN M. 2008b. Importance of Closed-Loop Supply Chain Relationships for Product Remanufacturing, International Journal of Production Economics, Volume 115, Issue 2, pp 336-348. 

7 APPENDED PAPERS 


\section{Appended Papers}

The articles associated with this thesis have been removed for copyright reasons. For more details about these see:

http://urn.kb.se/resolve?urn=urn:nbn:se:liu:diva-107496 


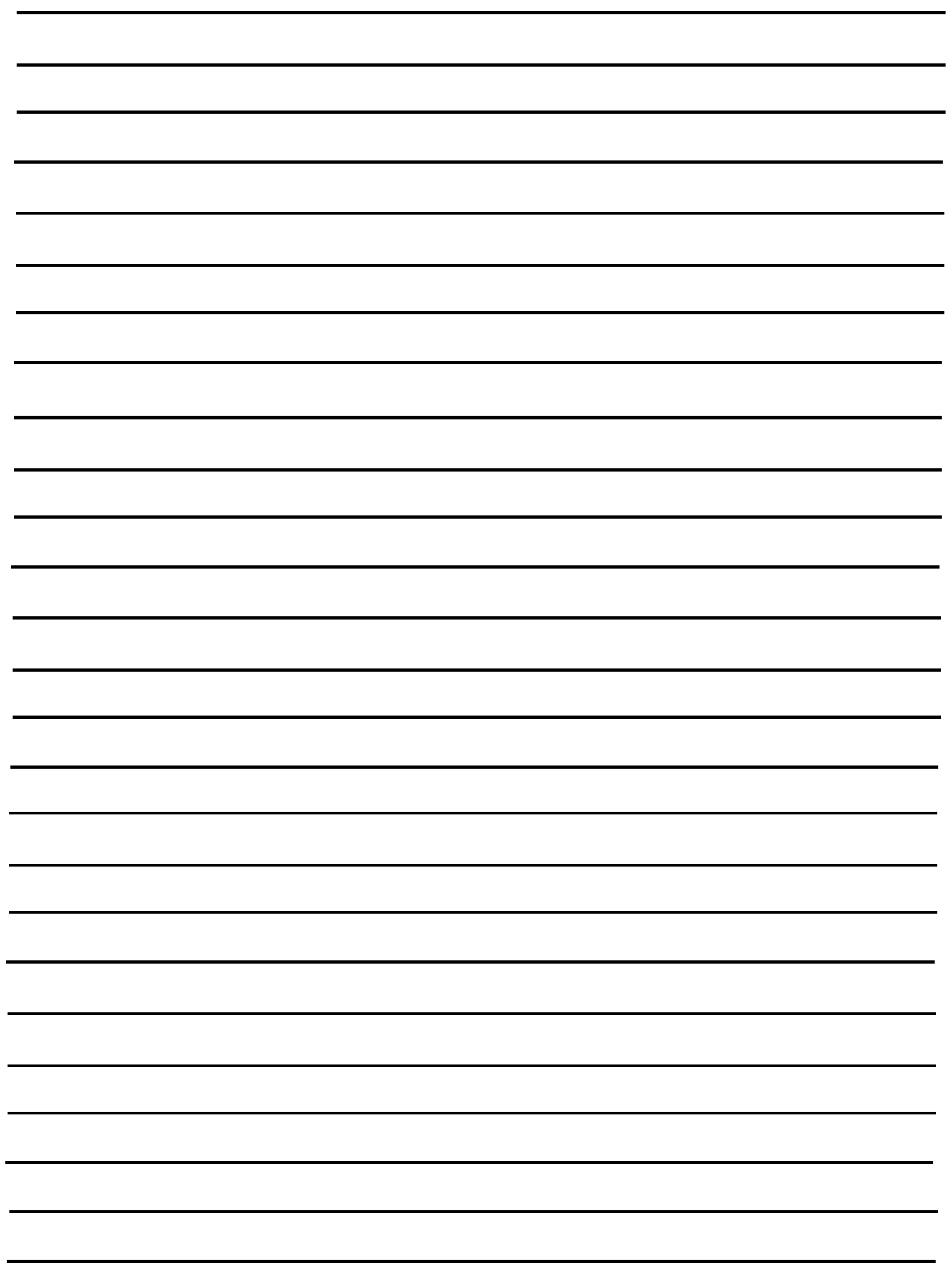




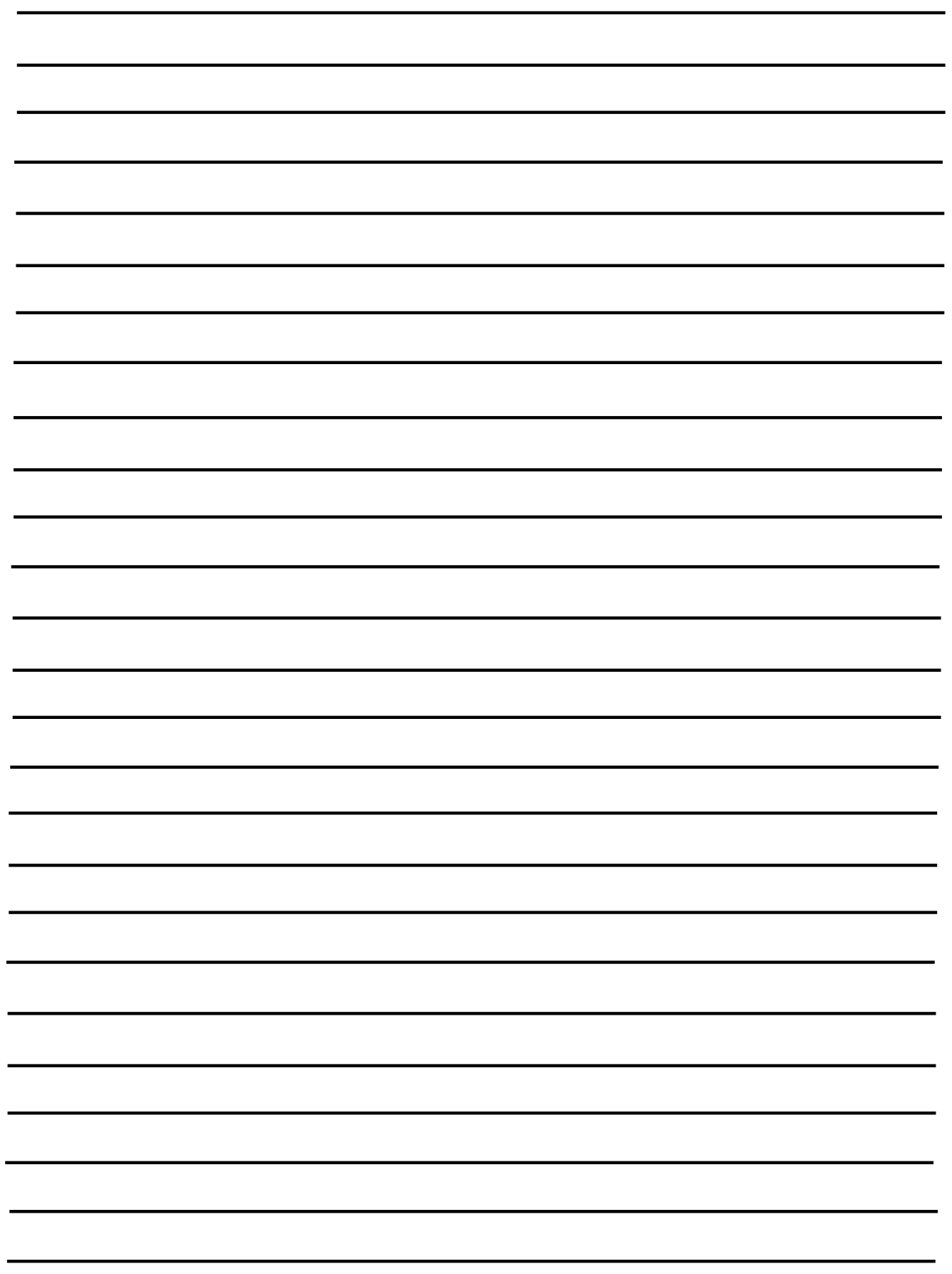




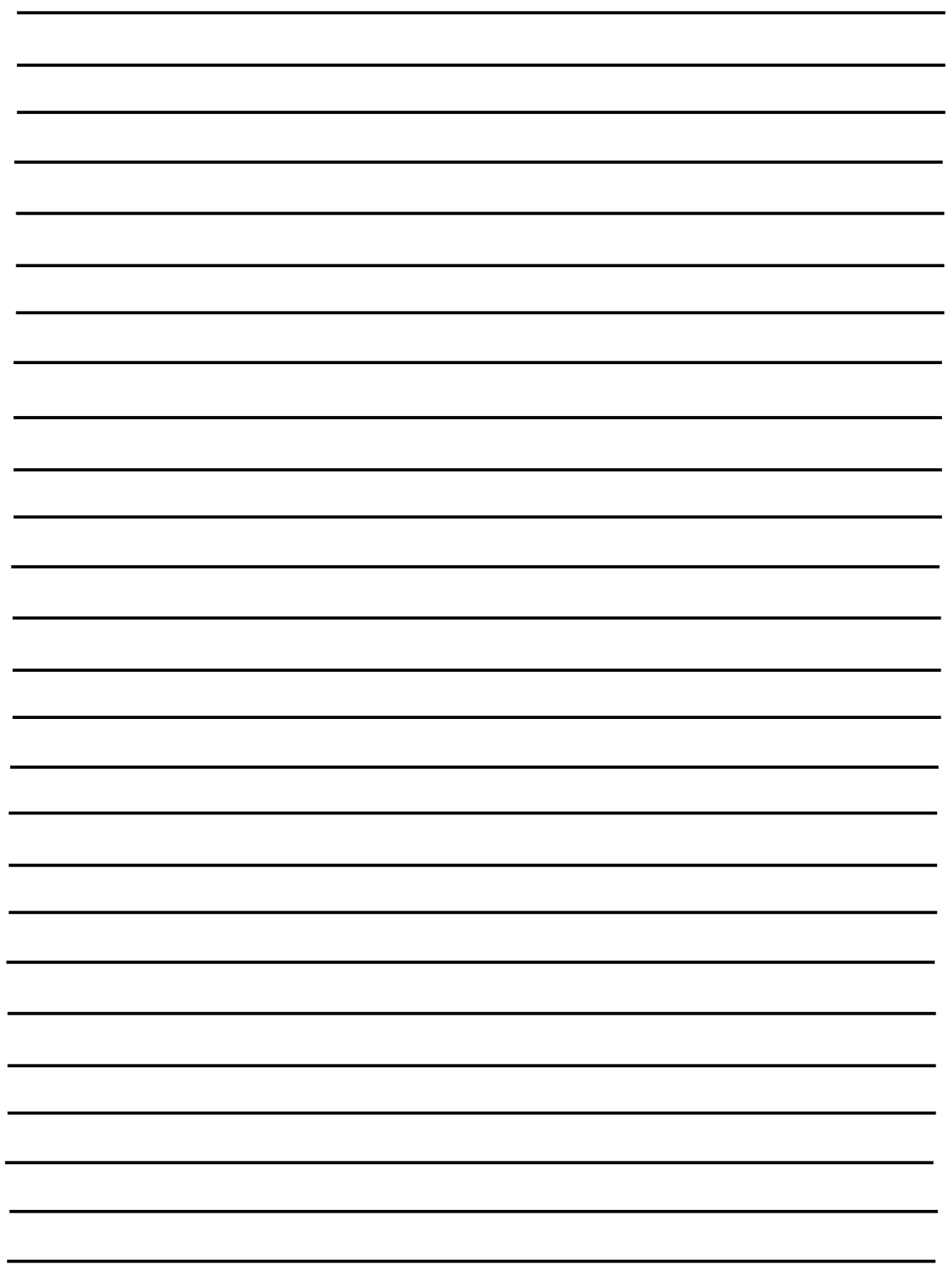




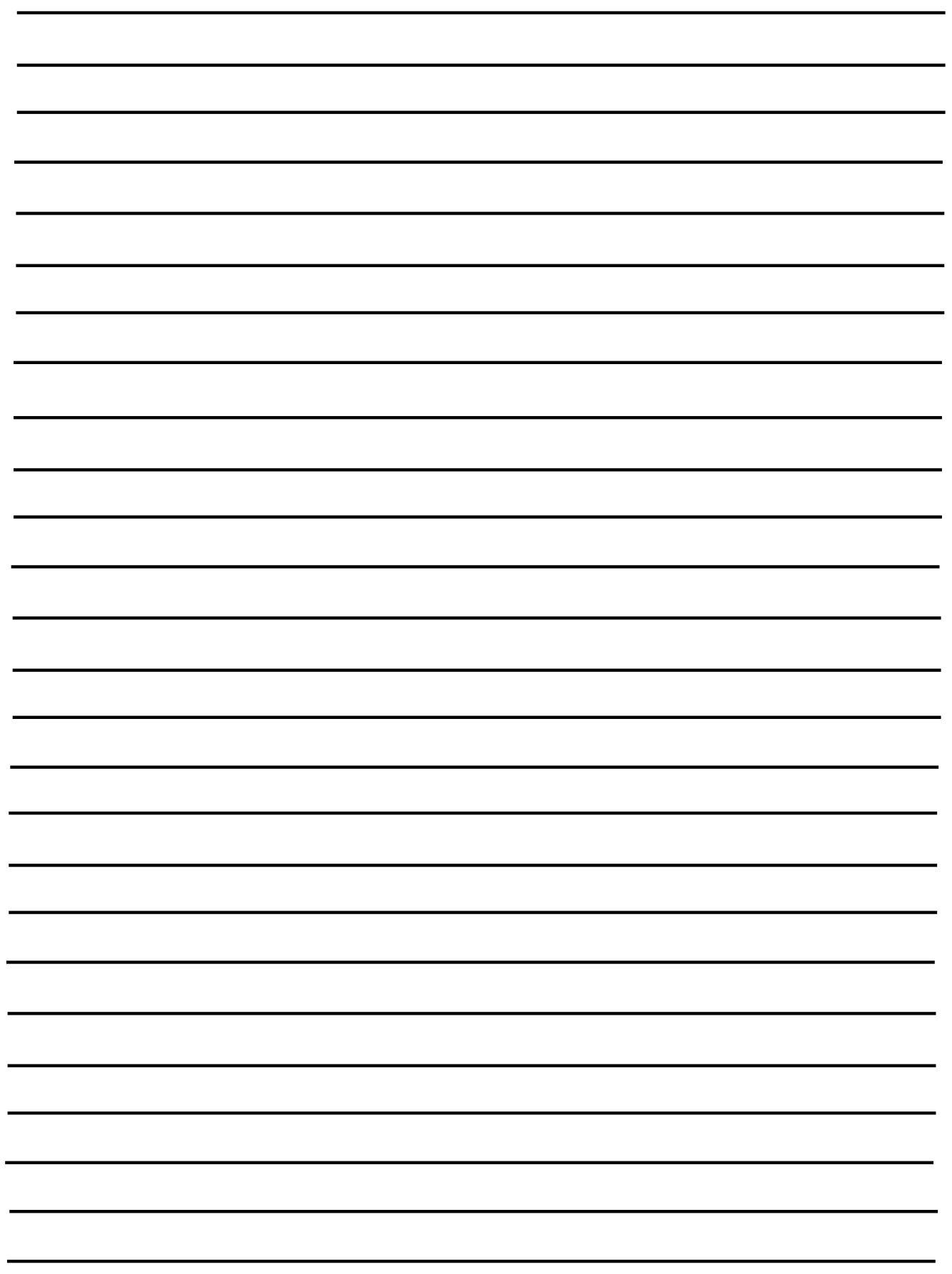




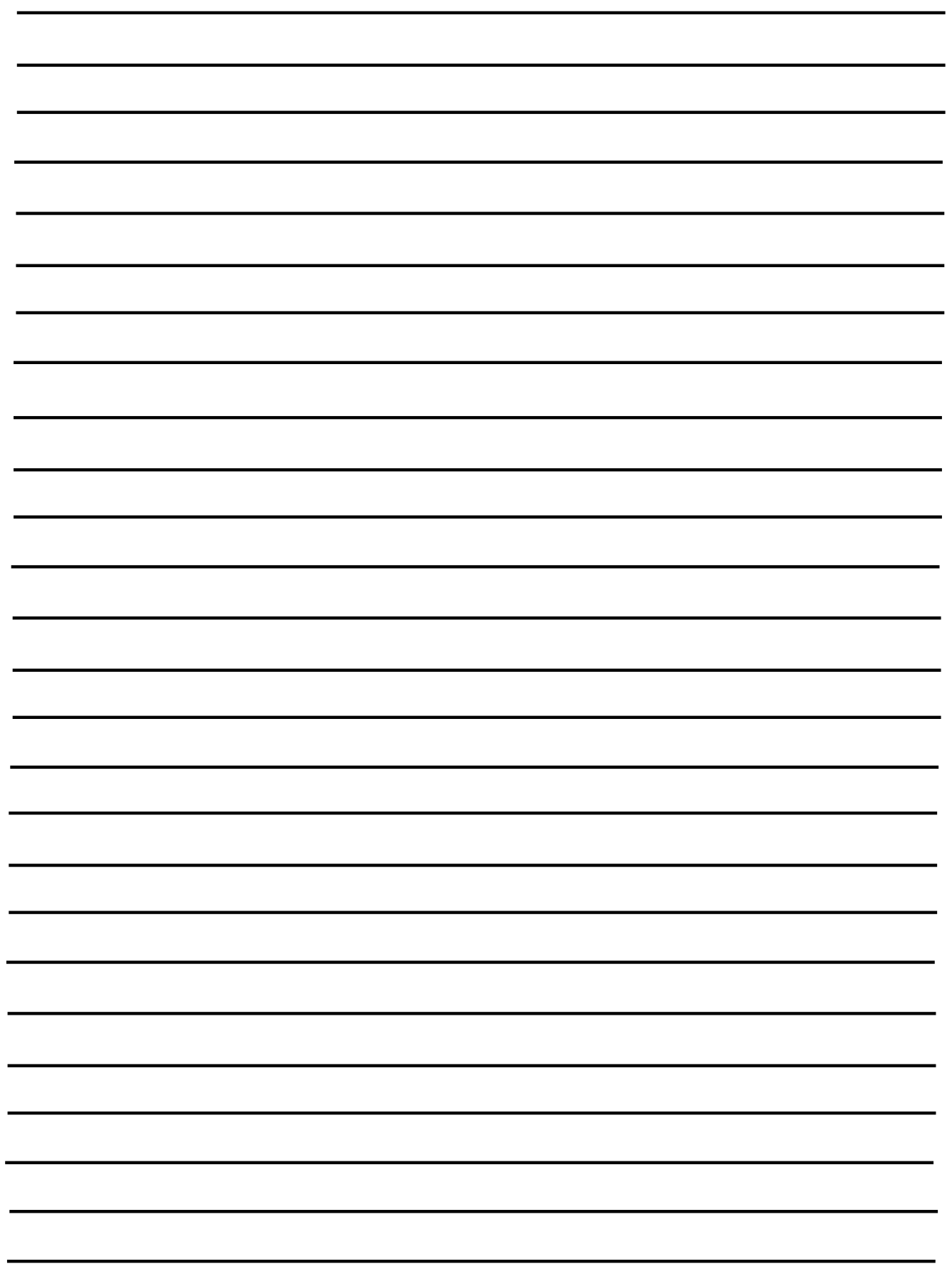




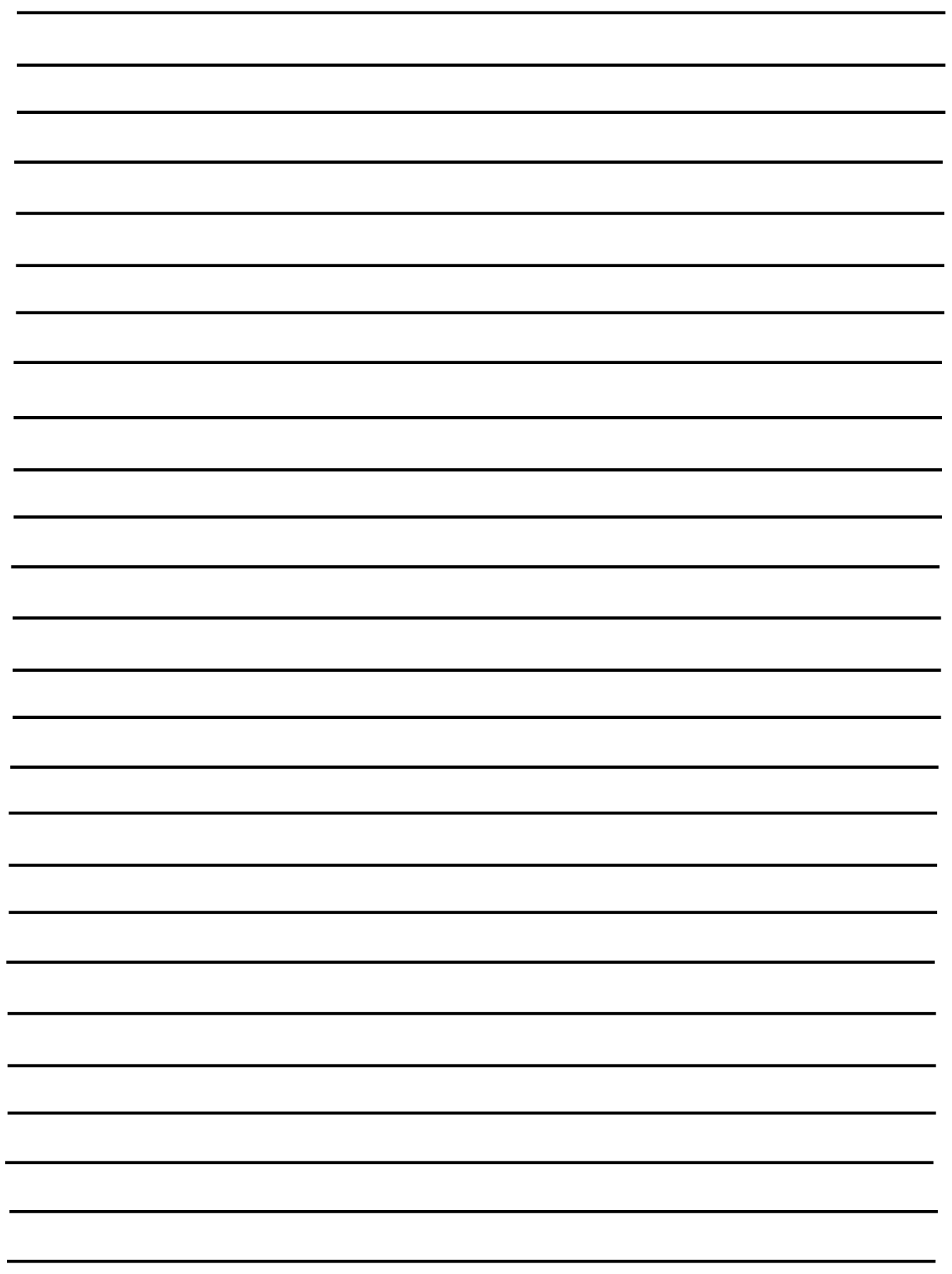




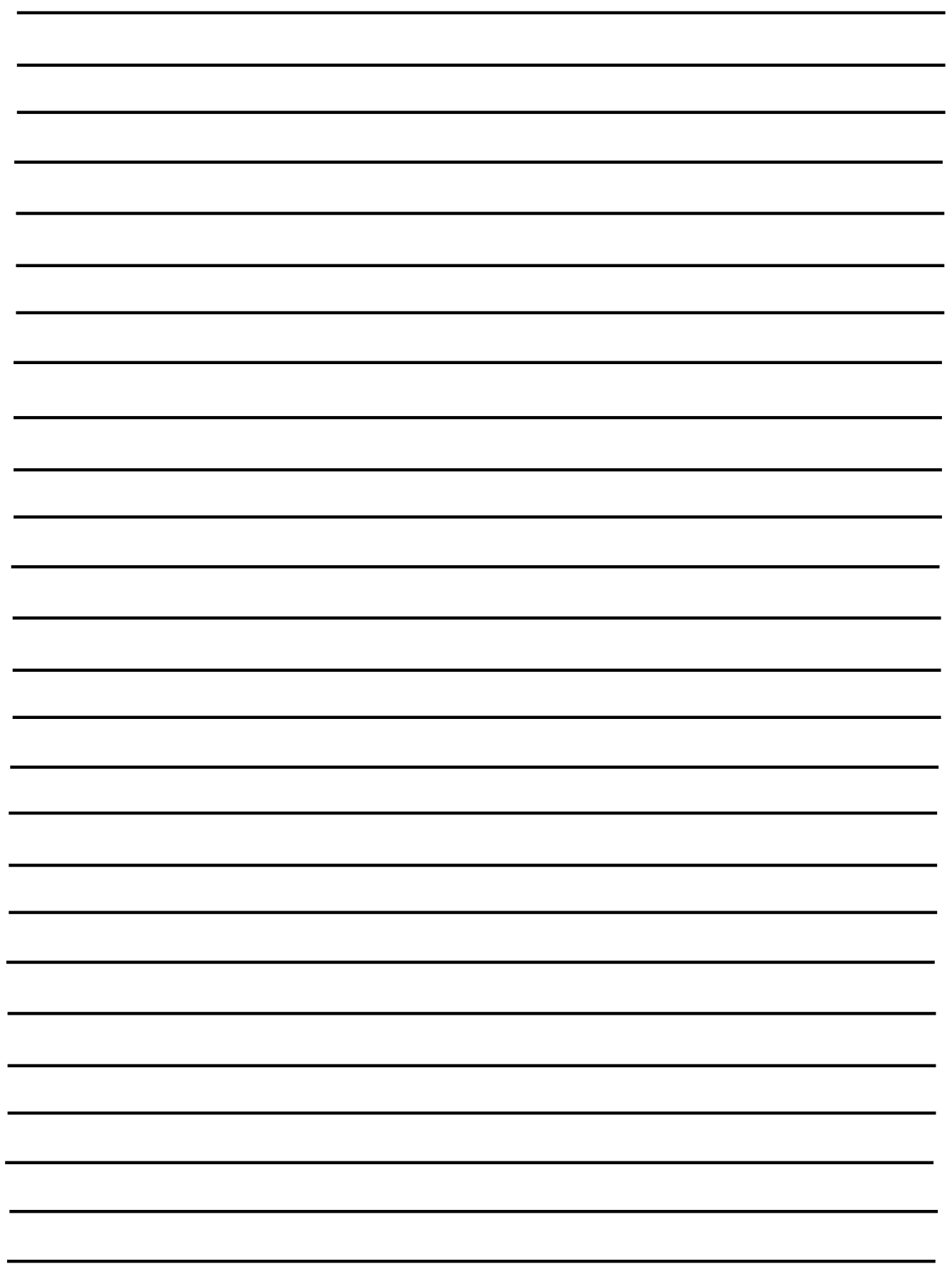




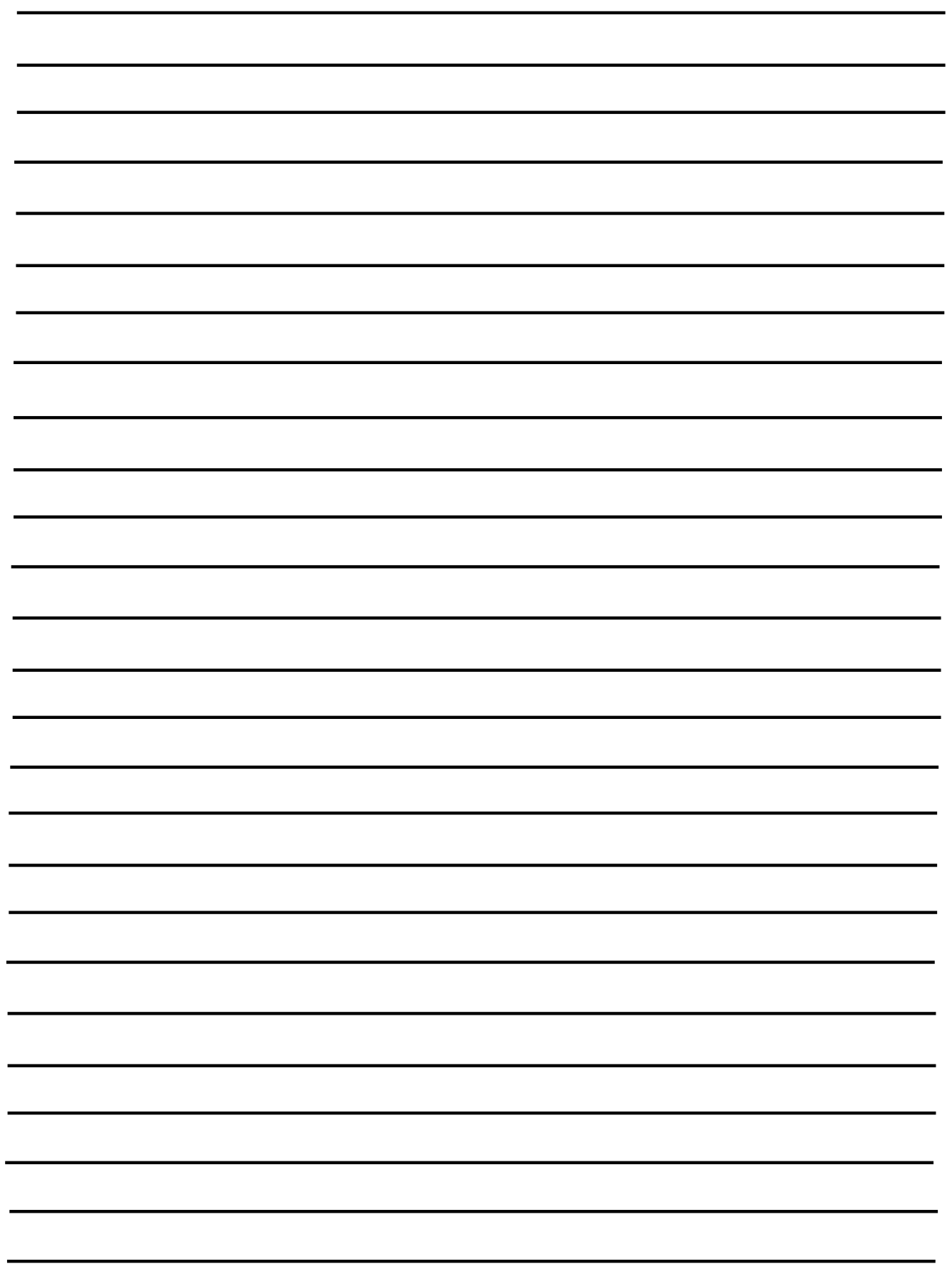



